\title{
FINE-TUNING THE NSP:
}

Discussions of Problems and Solutions with Facilitating Partners 


\section{FINE-TUNING THE NSP: Discussions of Problems and Solutions with Facilitating Partners}
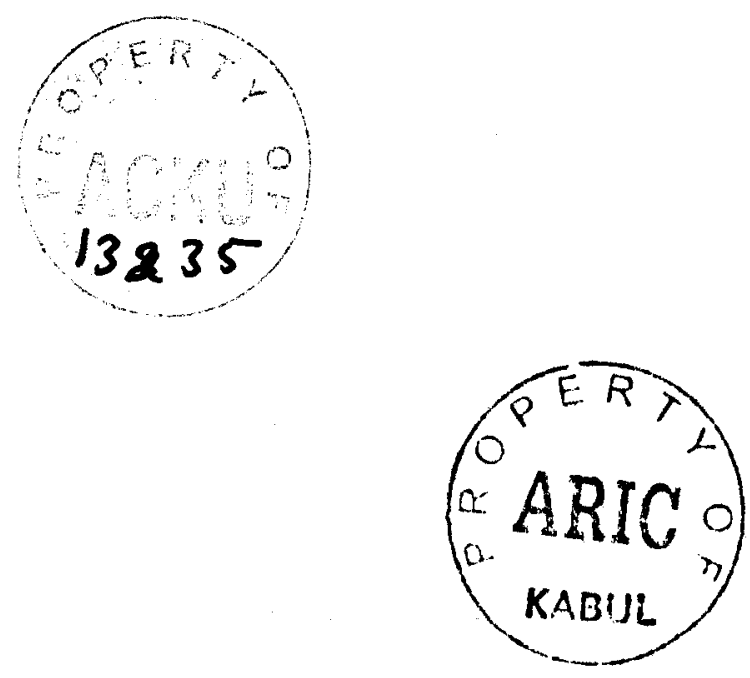

Palwasha Kakar

November 2005

Funding for this research was provided by the UK

Department for International Development (DFID)

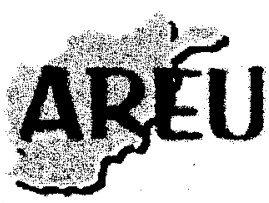


○ 2005 Afghanistan Research and Evaluation Unit. All rights reserved.

The views and opinions expressed in this report do not necessarily reflect the views of AREU. 


\section{About the Author}

Palwasha L. Kakar is currently the Local Governance Research Officer specifically focused on the National Solidarity Programme research at the Afghanistan Research and Evaluation Unit. An Afghan American, she has been researching local governance in Afghanistan for over a year now. She has a master's degree focusing on gender, politics and religion with a specific emphasis on Afghanistan and the surrounding region from Harvard University, USA. Prior to joining AREU, she was involved in research regarding Afghan customary law, Afghan women's identity, and social spaces in Afghanistan. She has also published papers on female prophets and saints in Islam.

\section{About the Afghanistan Research and Evaluation Unit}

The Afghanistan Research and Evaluation Unit (AREU) is an independent research organisation that conducts and facilitates action-oriented research and learning that informs and influences policy and practice. AREU also actively promotes a culture of research and learning by strengthening analytical capacity in Afghanistan and by creating opportunities for analysis and debate. Fundamental to AREU's vision is that its work should improve Afghan lives.

AREU was established by the assistance community working in Afghanistan and has a board of directors with representation from donors, UN and multilateral organisations agencies and non-governmental organisations (NGOs).

Current funding for AREU is provided by the United Nations Assistance Mission in Afghanistan (UNAMA), the European Commission (EC), the United Nations High Commissioner for Refugees (UNHCR), Stichting Vluchteling (SV), the World Bank, the United Kingdom Department for International Development (DFID), and the governments of Sweden, Switzerland, Denmark and Canada.

Funding for this working paper was provided by DFID. 


\section{Acknowledgements}

This paper is the result of much truth telling and people committed to communitydriven development in Afghanistan sharing their honest experiences and ideas about the National Solidarity Programme (NSP). I would like to thank all the NSP Managers, Coordinators, Directors and Engineers who contributed their time and with patience described the richness of various aspects of the NSP to me. These include: Elizabeth Kronoff (formerly ACTED), GB Adhikari and Fazal Ali (ActionAid), Mal Simmons (formerly AfghanAid), Steve Mason (AKDN), Shah Jahan and Jahangir Hussain (BRAC), Michelle Kendall and Eng. Nader (CARE), Waheed Hamidi and Wali Farhodi (CHA), Lyn Wan (formerly DACAAR), Abdul Sattar (DACAAR), M.E. Zeerak (GRSP), Dr. Mirzazada and Farishanoh Ofariaeva (GAA), Melissa Payson and Usman Tariq (IRC), Marie Brillet and Mr. Safi (MADERA), Lubna Bhayani (Okenden), Shah Wali (formerly OXFAM), Hakan Torngard (formerly SCA), Dr. Zia Shafaq (SDF), Fritz Szilard and Mr. Sawayz (UN-Habitat).

I would also like to give special thanks to my supervisor and mentor on this project, Sarah Lister, for the direction, thoughts and support she has given me.

Finally, I would like to thank all who took the time to review my paper and make provocative remarks and comments without which this paper would not be what it is. Thanks to Asif Rahimi (MRRD), Andreas Schild (MRRD/NSP-OC), Anne Johnson (formerly MRRD/NSP-OC), Homaira Nassery (WB), Norman Piccioni (WB), Usman Tariq (IRC), Dr. Faizullah Kakar (MoPH), Paul Fishstein (AREU), Hamish Nixon (AREU), Daud Omari (AREU), and Joyenda Mir Ahmad (AREU).

A special thanks belongs to Brandy Bauer (AREU) for comments, editing, keeping me sane and putting the final touches on this paper. 


\section{Contents}

Executive Summary 1

1. Introduction 4

1.1 Background on this research and methodology 5

2. Power Structures at the Local Level 7

2.1 Traditional local powerholders 8

2.2 Conflict and change: the legacy of multiple power structures 11

2.3 Where the NSP fits in 12

2.4 Summary 22

3. Forms of Women's Participation 23

3.1 Types of CDCs and women's participation in them 23

3.2 Other challenges to women's participation in the NSP 27

3.3 Summary 28

4. Potential NSP Linkages to Other Institutions 29

4.1 The World Bank's Integrated Approach 30

4.2 Three promising examples of CDC integration 34

4.3 Risk factors: local agents' overload and burn out 37

4.4 Role of CDC Clusters 38

4.5 Summary 38

5. Conclusions and Recommendations 40

$\begin{array}{ll}\text { References } & 42\end{array}$

Recent Publications from AREU 44 


\section{Glossary}

alagadars

beg/sardarl

khan/nawab/

zamindar

jerib

jihad

jirga/shura

kariyadars

malik/arbab

mantega/howzal

muhallah

mirab

mujaheddin

mukhi/mukhiyani

mullah

Pashtunwali

qazi

seer

Shariah

ulema sub-district level leaders appointed by government (set up following the 1964 Afghan Constitution)

large landowners

unit of land measurement; approximately $1 / 5$ of a hectare

holy war

tribal/community councils

popularly elected village leaders (set up following the 1964 Afghan Constitution)

traditional economically powerful village leaders

area, ward, territory or cluster of villages with a linked identity

village water controller

holy warriors fighting in jihad

Ismaili term for community religious leaders

religious teacher, mosque prayer leader

indigenous code of conduct among Pashtuns

religious judge

unit of measurement of weight, equivalent to approximately seven $\mathbf{~ g g}$ of grain

Islamic law

(religious) scholars 


\section{Acronyms}

$\begin{array}{ll}\text { ACTED } & \text { Agency for Technical Cooperation and Development } \\ \text { AKDN } & \text { Aga Khan Development Network } \\ \text { AREU } & \text { Afghanistan Research and Evaluation Unit } \\ \text { BDN } & \text { Basic Development Needs Programme } \\ \text { BPHS } & \text { Basic Package of Health Services } \\ \text { BRAC } & \text { Bangladesh Rural Advancement Committee } \\ \text { CDC } & \text { Community Development Council } \\ \text { CDD } & \text { Community Driven Development (programmes) } \\ \text { CDP } & \text { Community Development Plan } \\ \text { CHA } & \text { Coordination of Humanitarian Assistance } \\ \text { CIDA } & \text { Canadian International Development Agency } \\ \text { DACAAR } & \text { Danish Committee for Aid to Afghan Refugees } \\ \text { DANIDA } & \text { Danish International Development and Assistance Agency } \\ \text { DFID } & \text { (UK) Department for International Development } \\ \text { FP } & \text { Facilitating Partner } \\ \text { GAA } & \text { German Agro Action } \\ \text { GRSP } & \text { Ghazi Rural Support Programme } \\ \text { IRC } & \text { International Rescue Committee } \\ \text { MAAH } & \text { Ministry of Agriculture, Animal Husbandry and Food } \\ \text { MADERA } & \text { Mission d'Aide au Developpement des Economies Rurales en } \\ & \text { Afghanistan } \\ \text { MoEd } & \text { Ministry of Education } \\ \text { Mol } & \text { Ministry of Interior } \\ \text { MOPH } & \text { Ministry of Public Health } \\ \text { MRRD } & \text { Ministry of Rural Rehabilitation and Development } \\ \text { NEEP } & \text { National Emergency Employment Programme } \\ \text { NPP } & \text { National Priority Programme } \\ \text { NSP } & \text { National Solidarity Programme } \\ \text { OC } & \text { Oversight Consultant } \\ \text { SACRA } & \text { Special Action Committee for Religious Affairs } \\ \text { SCA } & \text { Swedish Committee for Afghanistan } \\ \text { SDF } & \text { Sanayee Development Foundation } \\ \text { UC } & \text { Union Council (Pakistan) } \\ \text { UNAMA } & \text { United Nations Assistance Mission in Afghanistan } \\ \text { USAID } & \text { United States Agency for International Development } \\ & \end{array}$




\section{Executive Summary}

Since mid-2004, the Afghanistan Research and Evaluation Unit (AREU) has been studying the National Solidarity Programme (NSP), one of the Afghan government's National Priority Programmes, in order to better understand changes to power relations in rural Afghanistan as a result of the NSP. This working paper presents preliminary evidence gathered from interviews with Facilitating Partners (FPs) of the NSP, conducted in Kabul between February and March 2005, as well as information gathered from initial fieldwork in Bamyan, Herat, Faryab and Nangarhar.

Discussions with FPs highlighted three key areas of concern as the NSP moves forward: negotiating with local powerholders, assuring women's equitable participation in the programme, and finding means to sustain the programme after the FPs pull out of communities.

\section{Negotiating with local powerholders}

Many changes in local and central governance over the last century have led to multiple existing power structures at the local level that the NSP Community Development Councils (CDCs) have to compete with for legitimacy and authority. This causes problems in the areas of:

- Signing the initial social contract between the community and the FP or agreeing to accept the terms of the NSP in the community;

- Electing CDC members to create a new council that may not include all powerholders in the community in the process;

- Attempts at controlling projects of one or many communities to the benefit of one commander; and

- Maligning the NSP on religious grounds.

Yet traditional institutions such as Maliks, jirgas, etc. are networks that sustain meaningful practices of decision-making that are acceptable and legitimate within a communal worldview and are significant vehicles for political action. Some FPs have found that bridging formal institutions with traditional institutions successfully forms communally acceptable governance institutions at the local level and creates greater "buy-in" to the NSP while not diluting the democratic process.

\section{Recommendations}

- Invite powerholders to advise the CDCs through councils.

- Facilitate general inter-ministerial cooperation on strategies to integrate the CDCs into the official government system, especially with the Ministries of Interior, Health, Education and Agriculture and Animal Husbandry.

\section{Increasing women's participation in the NSP}

Regardless of whether communities have women-only CDCs or women serve on mixed gender councils, women and women's CDCs lack legitimacy, meaningful participation and access to pertinent information in relation to male CDCs and the NSP's process in the community. Some causes of this are:

- FPs' staff gender bias;

- Cultural norms that prevent women from voting, being elected and attending meetings; 
- No formal system of integrating women's participation/decision-making or equal access to information and funds;

- Lack of time for FPs to educate and overcome biases; and

- Women's lack and feeling of lack of leadership experiences due to low literacy.

\section{Recommendations}

- Increase female staff and gender awareness to decrease gender biases in training.

- Legitimise women's participation through powerholders (eg. using religious leaders to support the Islamic principles of women's rights).

- Create structured routes of communication and authorisation between men's and women's CDCs.

- Build women's capacity as community leaders.

\section{Exit strategy/sustaining the NSP}

As the NSP comes to an end with the first round of targeted communities, effective exit strategies are being sought that strengthen legitimacy and sustainability. CDC clusters are a valuable point of contact for central government and non-government institutions to interact with the local level.

Likewise, CDCs have much un-reaped potential in augmenting the government's capacity to provide services at the local community level. CDCs have proven this potential in three cases:

- Disaster management: Generating damage assessments and beneficiary lists, mobilising local relief from surplus stocks, and expediting distribution of all forms of relief.

- Health: Participating on health councils, supervising health programmes, lobbying for improvements, surveying the community, lending themselves to be health educators, and monitoring and tracking disease and mortality.

- Education: Building criteria, generating proposals, lobbying and monitoring school projects.

One point noted by all the FPs was that CDC volunteer work can be time consuming and burden members and their families by taking them away from income earning activities. This in turn has a direct effect on the level of CDC outcomes and thereby the CDC legitimacy within their community.

\section{Recommendations}

- Create CDC clusters that:

$>$ Develop a cluster level development plan.

$>$ Lobby' for projects to government and non-government institutions.

$>$ Implement projects at cluster and village levels.

- Build cooperative links between CDCs and governmental and nongovernmental institutions that:

\footnotetext{
${ }^{1}$ In the context of this paper, the term "lobby" is used with the meaning to advocate for a specific action to be taken. For example, the CDC head may lobby to an NGO for culverts to be built in their village by describing the need in the village, how the project fits with the goals of the NGO and giving a project outline or summary with an estimated budget.
} 
Facilitate integration with new policies

Plan strategies (strategic planning) of how to integrate CDC cluster

Allocate resources to implement plan

Provide technical assistance to CDC projects

Supervise and Monitor Implementation of CDC projects

- Consider paying CDC members a small stipend to meet the income gap and to increase time able to be devoted to CDC work. 


\section{Introduction}

The National Solidarity Programme (NSP), one of the Afghan government's National Priority Programmes (NPP), has been touted as one of the most successful Community Driven Development programmes (CDDs) in the world to date. ${ }^{2}$ Begun in mid-2003, the NSP is a large scale rural reconstruction and development programme that has two major objectives: (1) to lay the foundations for strengthening community-level governance, and (2) to support community-managed sub-projects comprising reconstruction and development that improve access of rural communities to social and productive infrastructure and services. ${ }^{3}$

The NSP is executed by the Ministry of Rural Rehabilitation and Development (MRRD) and funded through the International Development Association and the Afghanistan Reconstruction Trust Fund, whose funders include the World Bank, the UK Department for International Development (DFID), the Danish International Development and Assistance Agency (DANIDA), the Canadian International Development Agency (CIDA) and the US Agency for International Development (USAID). Two consultant firms, GTZ and DAl, form the Oversight Consultant (OC), and work to strengthen capacity for community development and programme management within the ministry.

MRRD reaches the communities to implement the NSP through Facilitating Partners (FPs). FPs are responsible for initiating the NSP and providing technical and capacity building support to the communities. FPs follow the NSP Operational Manual to implement the NSP in the communities for which they are contracted, which includes assisting with the election of the democratic and representative Community Development Councils (CDCs), which form the basis of the programme. "Communities" are loosely defined as either based on existing government records of registration or of 25 to 2,000 families. Communities are educated about the NSP, mobilised and surveyed by Social Organizers trained and sent by the FP. The Social Organizers are further helped by Community Facilitators who are hired from within the communities. FPs may also have election experts to implement the CDC elections. FPs also have engineers who provide technical assistance in designing and implementing the projects of the CDCs.

The NSP supports the principle of universal suffrage and prioritises the inclusion of women in both elections of CDCs and decision-making through these bodies. However, the programme also recognises the challenges associated with operating in culturally conservative communities, and rather than mandating women's participation, allows FPs the flexibility to attempt to gradually increase women's decision-making power within the NSP framework.

CDCs are elected through a process of 1) identifying eligible voters, 2) creating voting clusters of 25 families, and 3 ) having at least 80 percent of each cluster vote for a representative (if men and women have a separate $C D C$, then they vote for separate representatives). Once $C D C s$ are elected, they then vote amongst themselves for a CDC president, deputy, secretary and treasurer. There are two main types of CDCs: a) joint male and female CDCs with a joint bank account, and b)

\footnotetext{
${ }^{2}$ A. Christensen, AREU interview with Senior Operations Officer of the Rural Development Sector Unit, WB Office, Kabul, Afghanistan, Dec. 16, 2004.

${ }^{3}$ NPP Strategy Document for the National Solidarity Programme, 2004, Prepared by the JPU for NSP, June 2004.
} 
separate male and female CDCs with a joint bank account. Through the CDC representatives, the whole community is involved in an inclusive process to identify their top development projects and to create their Community Development Plan (CDP). The FP then trains the CDC members in project proposal writing, accounting and procurement. The CDC submits their development project proposals to MRRD and the Oversight Consultant. If the proposals are approved, MRRD then sends money in instalments ${ }^{4}$ to the CDC's bank account and the CDC implements the project. The CDC continues to report to MRRD and to the community about the project's implementation process and budget.

MRRD plans to reach all communities in Afghanistan through the NSP as long as funding permits. In the first year of the programme, three districts in every province were targeted by MRRD, so that 6,000 communities were reached. In the second year, the target was expanded to reach an additional 4,500 communities, so that roughly half of Afghanistan was covered. This year, 2005, NSP's third year, there is still discussion as to the exact number of communities targeted, however, the number is around 6,000 more communities to be reached.

\subsection{Background on this research and methodology}

As one of the more prominent National Priority Programmes, the NSP attracted the Afghanistan Research and Evaluation Unit's (AREU) interest at the same time that Hanif Athmar, Minister of Rural Rehabilitation and Development, asked AREU to research its implementation. This work falls within AREU's overarching governance research, which seeks to understand shifts in local power dynamics and changing relationships between central and local governance structures. AREU subsequently was provided with funding to research the NSP from DFID, one of the NSP's donors.

This is the second "working paper" in a series of publications on the NSP that is an outcome of such support. This working paper is mainly based on interviews with FPs in Kabul, Afghanistan conducted between February and March 2005. These interviews sought to get an overview of the NSP and to inform AREU's NSP field research regarding the links between implementation and outcomes that are related to shifts in power and resistance.

The main body of research that this paper relies on is the interviews conducted with NisP managers of the Facilitaiing Partiners. Of the 24 FPs, 17 were interviewed. This was based on the responsiveness of the FPs and their availability. Those interviewed were: the Aga Khan Development Network (AKDN), ACTED, ActionAid, AfghanAid, Bangladesh Rural Advancement Committee (BRAC), CARE International, Coordination of Humanitarian Assistance (CHA), Danish Committee for Aid to Afghan Refugees (DACAAR), German Agro Action (GAA), Ghazi Rural Support Programme (GRSP), International Rescue Committee (IRC), MADERA, Ockenden International, OXFAM, Swedish Committee for Afghanistan (SCA), Sanayee Development Foundation (SDF), and UN-Habitat.

The overall objective of AREU's NSP research is to gauge NSP's stated goal of "empowerment" through understanding changes to power relations in rural Afghanistan as a result of NSP. While there are many international experiences of CDDs to draw from, this paper takes a closer look at the specific challenges and lessons learned of implementation related to "empowerment" and power relations

\footnotetext{
${ }^{4}$ Money is sent usually in two to three instalments, depending on the overall project amount.
} 
faced in the post/conflicted Afghan context. While some evidence may suggest that the NSP is more successful than most CDDs, obstacles and challenges to achieving these goals still abound.

This paper represents the preliminary findings in an ongoing research programme that includes evidence from field research in Herat and Faryab. A short case study in Bamyan during November 2004 and a desk-based study of international experiences also contributed to this paper. Ongoing NSP field research is continuing in Herat, Faryab, Bamyan, Nangarhar, Kandahar and Badakhshan. The next paper based on these field studies is planned for release at the beginning of 2006.

This paper explores inter- and intra-relational issues of CDCs at a local (communal and sub-district) and national (district, provincial and countrywide) level that came out of discussions with the FPs. The two decades of conflict and social disruption have left a myriad of competing power structures in its wake. As the NSP adds the CDCs to this mix, it too joins in the jostle for both communal and governmental legitimacy drawing in new power from marginalised groups, including women. At the same time, within the CDCs, women are struggling for the legitimacy of their decisions and for their opinions to be taken into account with the men's. At a national level CDCs are better able to sustain themselves when supportive links with other structures and institutions are built. However, at a local level, CDCs' development projects require CDC members to devote time away from livelihoods generation, thus burdening families.

This paper is organised into three sections, based on salient topics that emerged out of the discussions with FPs. The first section deals with existing/traditional power structures, outlining them, their points of interaction with CDCs and pro-active integration; it also highlights the somewhat controversial issue of payment of CDC members. The second section deals with forms of women's participation, outlining the various types that have been used in the NSP and those that give women's decisions legitimacy within a CDC. The third section deals with the benefits of building links between local and central government institutions and ways in which links between CDCs and other institutions have been built in the areas of disaster management, health and education. Each section outlines the challenges faced by FPs and identifies some ways in which they have been able to address them. 


\section{Power Structures at the Local Level}

One of the NSP's challenges in forming new CDCs in areas where the NSP is not a familiar programme is gaining local communal legitimacy and authority. Afghanistan's experience of war has left the country with multiple power structures. As each new regime took over an area, a new set of power structures emerged. Historically Afghanistan's central state did not interfere with local traditional power structures from 1880 till 1973.5 Traditional power structures governed the rural villages and mantegas (area, ward or cluster of villages with a linked identity) with relatively little interference from the state during this time. ${ }^{6}$ As different forms of the Afghan state attempted to fashion national unity based on ideologies from Communism to extreme forms of Islamism, new representatives of the central government were appointed to govern the rural areas. All of the legacies of past regimes and traditional power structures have left their mark on villages and mantegas. Now, as the new government tries to stabilise the country, it has to reckon with these multiple power structures at the local level. The NSP is one of the Afghan government's ambitious projects that aims at such stability and faces, head on, these multiple power structures.

This section will outline some of the basic existing power structures (which vary across geographical region), ${ }^{7}$ how they have formed over time, how this has affected CDCs and how CDCs have met these challenges-retro-actively and pro-actively. Table 1 briefly summarises the different local-level powerholders and their responsibilities.

Table 1: Summary of local-level powerholders and their responsibilities

\begin{tabular}{|l|l|l|}
\hline POWERHOLDER & OTHER TERMS & TRADITIONAL ROLES \\
\hline Malik & Arbab, Karyadar & $\begin{array}{l}\text { Power broker and representative between community and central } \\
\text { power/government, communal dispute resolution and maintenance of } \\
\text { communal property }\end{array}$ \\
\hline Mirab & Khadadar & Controller of community water canal \\
\hline Khan & $\begin{array}{l}\text { Zamindar, Beg, } \\
\text { Sardar } \\
\text { Nawab, Arbabs }\end{array}$ & $\begin{array}{l}\text { Large landowner who controls many resources in the community along } \\
\text { with providing jobs to labourers and land to sharecroppers; may also } \\
\text { arbitrate conflicts }\end{array}$ \\
\hline Ulema & $\begin{array}{l}\text { Mullah, Talib, } \\
\text { Qazi, Sufi. Mukhi, } \\
\text { Mukhiyani }\end{array}$ & $\begin{array}{l}\text { Religious leaders who lead prayers, give sermons and have the power } \\
\text { of moral iudgement in the community; also involved in resolving } \\
\text { conflicts from point ot view of Shari'ah }\end{array}$ \\
\hline Jirga & $\begin{array}{l}\text { Shura } \\
\text { range from disputes to maintenance of communal property. }\end{array}$ \\
\hline
\end{tabular}

\footnotetext{
${ }^{5}$ O. Roy, 2003, "Afghanistan: Internal Politics and Socio-Economic Dynamics and Groupings." UNHCRWriteNet Paper, 1-3. Also see A. Rasanayagam, 2003, Afghanistan: A Modern History, London: I.B. Tauris and A. Tarzi, 2003, The Judicial State: Evolution and Centralization of the Courts in Afghanistan, 1883-1896, Ph.D. dissertation, New York University.

"This lack of interference was largely a result of lack of capacity and lack of ideological agreement on the meaning of the "state", though too the idea of the nation state may have been significantly different than what the term implies in the West.

7 The scope of this paper does not include "warlords" or "drug lords" since it is based on FP interviews and those powerholders did not arise in these discussions. This is most likely because a warlord's power base is made up of local commanders who are aligned with the warlord. Therefore, it is the local commanders acting at the local community scale, even where a warlord may be involved.

DACAAR reported that Nawab was the term used for landlord, however, Nawab is more commonly used in the Indian sub-continent for large landowners. Arbab is used in the north for large landowners as well as for the community representative.
} 


\subsection{Traditional local powerholders}

\section{MALIKIARBAB}

For many years the traditional power broker between the community and whatever form of central power has been in place was the Malik (term used in the south) or Arbab' (term used in the north). This system is so old that it is unclear whether this position was originally appointed by a central power (such as in traditional Muslim state paradigms) $)^{10}$ or whether the Malik/Arbab was appointed by the community." Since Malik/Arbabs tend to be economically powerful people in the community, perhaps even large landowners, the latter argument is that the community chose someone with economic power to represent them because it was thought that they could get more done and the central powers would listen to them. Whatever the case may be, as time passed, the position was either inherited or re-appointed through community consensus. Outwardly, the Malik/Arbab represents the needs of the community to government officials and lobbies for projects needed by the community. Inwardly, the Malik/Arbab is a community point person for solving community problems. These problems may range from fixing communal property such as bridges, canals and roads to handling inter-relational conflicts. In some instances, the Malik/Arbab may call upon the help of the village elders' shura to resolve a problem. ${ }^{12}$

\begin{tabular}{|c|c|}
\hline $\begin{array}{l}\text { The Afghan Constitution of } 1964 \\
\text { tried to replace the } \\
\text { Malik/Arbab system with } \\
\text { Kariyadars and Alagadars. The } \\
\text { Kariyadars (from kariya or } \\
\text { village) were supposed to be } \\
\text { elected by the people and the } \\
\text { Alaqadars, at a sub-district } \\
\text { level (from which the term } \\
\text { arises), were appointed by the } \\
\text { government. }{ }^{13} \text { Anecdotal reports } \\
\text { claim that the Kariyadars } \\
\text { became another name for the } \\
\text { Malik/Arbabs and the Alagadar } \\
\text { system had collapsed by 1978. }{ }^{14} \\
\text { Daud's regime (1973-78) }\end{array}$ & 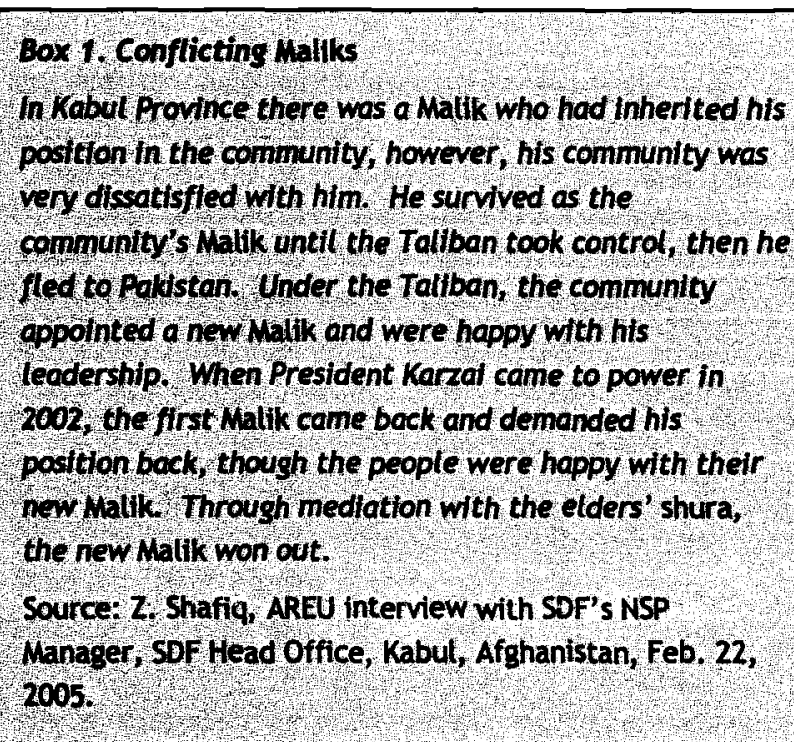 \\
\hline
\end{tabular}
Councils ${ }^{15}$ in mainly Pashtun areas of the country, who took on some of the roles of the Malik/Arbab by deciding the community vision, representing and lobbying to the government. However, the Community Based Councils mainly functioned as a

\footnotetext{
${ }^{9}$ Kariyadar is also used in the north after being introduced by the government. See next paragraph. ${ }^{10} \mathrm{~F}$. Vogel, 2003, "Understanding Muslim State Paradigms and Afghanistan," Afghan Legal History Project Lecture, Islamic Legal Studies Department, Harvard Law School, Cambridge, MA.

${ }^{11}$ L. Dupree, 1966, "Aq Kupurk: A Town in Northern Afghanistan," South Asian Series, $X(10)$ (Afghanistan):13.

12 lbid, 13.

13 Ibid, 2.

14 D. Omari, 2004, Notes on Paktiya.

15 Anecdotal reports indicate that these councils were possibly political party based (in Daud's partyMilli Ghorzang), but perhaps touted at official government councils. T. Usman, AREU Interview with IRC's NSP Manager, September 19, 2005.
} 
propaganda mechanism, spreading information to the people rather than informing the government of the needs of the people. ${ }^{16}$

The survival of a certain Malik/Arbab over the regime changes depended on whether the individual was able to get along with the various powers-commanders and governments-that took over their region. SDF reported a case that exemplifies the dilemma of the Malik/Arbab retaining communal power through the past 23 years of conflict (see Box 1).

\section{MIRAB ${ }^{17}$}

The Mirab traditionally has been the controller of water in the community. Sometimes appointed or consensually elected annually, he wields power through the control and management of precious water resources the community needs for their agriculturally based livelihoods. The Mirab is appointed based on his honesty and hard work. The Mirab is paid in various forms such as two Kabul seers of wheat per household to 20 jeribs of land ${ }^{18}$ or from 10-150 afs per hour of water management. When there are disputes over water within the community they are taken to the shura. The Mirab is in charge of maintenance of the village canal and has the power to call community members to repair them. Where the village is large, the Mirab may have a Saatchi (timekeeper) helping him. In the south the Mirab may be the second person in command under a Khadadar in controlling the community's water. In this case the Khadadar is the point person on water management, while the Mirab is the implementer. ${ }^{19}$

Mirab clusters of many villages in a manteqa in the north elect a leader called the Chak Bashi. In other places, district Mirabs are elected by villages farthest down stream to ensure equity. However, in the current situation local commanders with military force have prevented the district Mirabs from being able to manage and enforce water distribution rules. The village Mirabs in AREU's 2004 case study on water management ${ }^{20}$ flourished under the Taliban but have been all but extinguished from villages with the current unchecked rise of military power by local commanders.

\section{LARGE LANDOWNERS}

Depending on the ethnicity and communal structure of the community, a village had other traditional power structures. In areas that developed large landowners, the Begs (Uzbek), Sardars (Balouch), Khans and Zamindars (Pashtuns and Tajiks) of the region had and continue to have power through their wealth. Their power is mostly based on hereditary wealth rather than popularity or any trait of leadership. In communities where there are large landowners there is often a huge disparity between the wealthy and the poor. Along the same lines there is also a large disparity in power distribution, so that large landowners can become virtual rulers in their communities, since no one has enough power to challenge them. An Arbab/Malik may also be a large landowner, however, not all large landowners are Arbab/Maliks.

\footnotetext{
${ }^{16} \mathrm{H}$. Torngard, AREU interview with SCA's NSP Manager, SCA, Kabul, Afghanistan, March 19, 2005.

17 A. Pain, 2004, Understanding Village Institutions: Case Studies on Water Management in Faryab and Saripul, Kabul: AREU, 17-20.

${ }^{18}$ One seer equals approximately seven kilos of grain, while one jerib of land is the equivalent of $1 / 5$ hectare.

${ }^{19} \mathrm{~T}$. Usman, Peer review comments from IRC's NSP Coordinator, October 2005.

${ }^{20}$ See footnote 17.
} 
Large landowners have been able to retain much of their wealth and influence by being able to manage their land without being physically present. Landowners may have migrated to Pakistan or Iran when necessary but still kept control of their land. However, their hegemony over a given community does not necessarily continue in their absence. The existence of large landowners from famous large local families has frequently led to the formation of local commanders. The process was a militarisation of local solidarity groups. ${ }^{21}$

\section{RELIGIOUS LEADERS}

The religious leaders of a community or even a region traditionally have and continue to hold power and authority. They are often the most trusted and credible community members, as they are assumed to hold to high religious principles of behaviour. These include not only the Mullahs and Ulema but also the Sufi leaders and the Ismaili Muki and Mukiyanis.

In Afghanistan, traditionally Sufi leaders of the Mujedidi and Gailani families also had political influence. The Mullahs gained political power with the popularity of the political Islamist movements-both Shi'a and Sunni-during the mujahideen war between 1978 and 1992. This lead to the popularisation of Salafi elements being taught to religious students, particularly in Pakistan, that then fuelled the ideology behind the Taliban's rise to power. ${ }^{22}$ The Taliban represented the apex of religious leadership and control at local and central levels. However, the Taliban were not so much interested in running a state as they were in enforcing Shariah law on everyday life. Much of the Taliban's control ended up being at the local level and varied considerably in its rigour and adaptation to local existing power structures. ${ }^{23}$

\section{VILLAGE COUNCILS: JIRGAS AND SHURAS}

Despite the ethnic and cultural diversity of Afghanistan, many communities often have some form of council often called jirga in Pashtun areas and shura in other areas. Councils are usually made up of leaders from more than one village unless the village is large. The previously mentioned powerholders are usually a part of the council along with the elders of the community. Elders are usually men known as "white beards" who are respected in the community and have some clout either due to connections, wealth, reputation, oratory skills and/or conflict resolution skills. In tribal areas of Afghanistan, the tribal elders and leaders are also on this council. What is often misunderstood about traditional village councils is that they usually only meet when there is a problem and often the participation is varied according to who has the resources to solve the problem. Problems range from interpersonal conflict and land disputes to maintenance of communal property or intra-communal relations. Often the meetings are held in public so that other members of the village can gather around the circle of the council to listen and even comment, though the final decision rests with the participating council members. ${ }^{24}$

\footnotetext{
${ }^{21}$ Roy, Afghanistan: Internal Politics..., 4.

$22 \mathrm{~K}$. Mendoza, 2004, Islam and Islamism in Afghanistan, Afghan Legal History Project, Harvard Law School, Online at: http://www.law.harvard.edu/programs/ilsp/alhp.html.

${ }_{23}$ Roy, Afghanistan: Internal Politics..., 8.

24 And often, consensus is only necessary from the elders of the council, not the entire shura. Torngard, AREU interview of SCA's NSP Manager, March 19, 2005.
} 


\subsection{Conflict and change: the legacy of multiple power structures}

As changes in both central and local governance occurred, the Malik/Arbabs often changed at the village level, either by the new regime appointing another or by the new regime asking the community to appoint another. The Communists added Community Based Councils to the local governance mix, mostly in Pashtun majority provinces but also in strategic provinces such as Herat. The mujahideen resistance to the Communist regime added the first tier of commanders. When civil war broke out between the mujahideen parties, the leadership changed hands from ideological leaders to local solidarity group backed militias. Some large, regionally based commanders were able to build on ties of solidarity based on ethnicity (Hazara or Uzbek) or regional allegiances (Herat) to build up enough support among local commanders to become "warlords". Warlords were also supported by some form of revenue either through taxation, border control, control of local resources, drug trafficking or foreign aid of arms and money. ${ }^{25}$ Current AREU research on natural resource management findings indicate that the tables are turning and local-level commanders are gaining control of such forms of internal revenue from warlords. ${ }^{26}$

The Taliban added to these powerholders religious commanders loyal to Pashtun leadership and an ideological Islamic state. ${ }^{27}$ While the opposition to the Taliban had commanders take leadership in the areas the opposition controlled, these commanders were loyal to their ethnicities, such as Tajiks, Uzbeks and Hazaras.

Traditional local institutions of governance have proven their resilience and stability by their sheer capacity to continue to exist. Part of the reason they continue to exist is because they are part of the local paradigm or world view of their community. ${ }^{28}$ Historically, Afghanistan was governed like other Muslim states where the central government had little involvement and responsibility at the community level. Because there was little interference at the community level (apart from little taxation) local governance structures were run by the community in traditional ways specific to their region, developed and practiced over the centuries. This relative lack of formal interference in rural traditional forms of local governance continued until the Communist regime, where formal government interference met with much opposition.

As Olivier Roy puts it, "Traditional political forces have a need for a distant and benevolent state, whose existence they do not challenge..."29 Paradoxically, it was the Communist and Islamist movements-products of the Afghan modernisation process-that wanted a stronger authoritarian central government that interfered in the "fragile equilibrium" between the traditional political forces and the state. As Afghanistan tries to reconstruct this "fragile equilibrium," Roy is of the opinion that currently "there is no...ideological force committed to replacing the present regime." In other words, there is only competition between groups to increase their power or with the desire to help the state function better, not to change "the nature of the state" or to create a "wholly other one."

${ }^{25}$ Roy, Afghanistan: Internal Politics..., 6.

${ }^{26}$ B. Whitty, Drivers of Change Workshop at AREU, August 2005.

27 Roy, Afghanistan: Internal Politics..., 3.

$28 \mathrm{~T}$. Hohe, 2002, "Clash of Paradigms in East Timor," Contemporary South Asia, 24(3):570.

29 Roy, Afghanistan: Internal Politics..., 2.

${ }^{30}$ Ibid, $2 \cdot 3$. 


\subsection{Where the NSP fits in}

So where does the NSP fit into this understanding of sustainable governance in Afghanistan? The NSP is arriving on the scene where forms of local leadership-both traditional or not-have been changed by time and conflict. In this context the FPs face a multitude of problems arising from traditional or existing power structures. Their problems range from the first step of community mobilisation and signing the NSP contract to blocks on projects. Maliks, elders, Mullahs, commanderstraditional/existing power structures, each in various communities (not all communities)-have felt threatened and/or have sought ways to abuse the system.

The NSP interacts at the very local and core level of traditional power structures, whereas a sustainable Afghan government is perceived as a "distant and benevolent state." Instead of the central government sending representatives to be involved and dictate local affairs, the NSP can be seen as a re-structuring and re-alignment of meaningful traditional power structures that already exist in Afghan communities that can re-establish the "fragile equilibrium" of a sustainable Afghan state. According to one source, Amir Abdur Rahman did exactly this sort of re-shaping and re-aligning of "tribal aristocracy and religious establishment" to bring about the first semblance of a stable Afghan state that lasted till 1978. ${ }^{31}$

To best re-align these traditional power structures, the NSP needs the relevant ministries to work closely with MRRD to ensure full integration of the re-structured and re-aligned community institutions in the creation of a stable, sustainable, legitimate and functioning state. This may also give representatives of the government the opportunity to bypass commander structures at the local level and deal with the elected bodies of the CDCs, thereby de-legitimising commander power from the government since it is the local commanders that "need the state as a legitimising factor or as a power broker". ${ }^{32}$ However, the present capacity of CDCs vary, thus they are not consistent enough to be suitable as formal structures.

\subsubsection{Introducing the NSP to the communities}

The first step of the NSP is introducing the programme, the roles and responsibilities of the community, FP and government, and the basic requirements of the programme (eg. elections, community participation, transparency, accountability). Community leaders are asked if they agree to have the NSP implemented in their community and at this stage some FPs such as IRC have communities sign a "social contract" between the community and the FP stating that they understand the programme and agree to the regulations of implementation.

In the process of facilitating the creation of CDCs, FPs have encountered a number of obstacles with existing power structures, in particular related to the first step where communities agree to the implementation of the NSP. FPs have reported four popularly occurring reasons for why a given community in Afghanistan may not be willing to agree to the implementation of the NSP:

- No desire for a new council, ("we already have a leader and council") i.e. threatened by the formation of another structure;

- Lack of understanding about the objectives of NSP;

31 A. Ghani, 1978, "Islam and State Building in Afghanistan." Modern Asian Studies. 12(2):271.
32 Roy, Afghanistan: Internal Politics.., 6. 
- Will not allow women's participation (though FPs may waive this requirement in some areas); and/or

- Not taking the NSP and/or FP seriously.

Discussions with a former SDF staff member ${ }^{33}$ illustrate this first reason why many communities at first refuse the NSP because the traditional/existing powerholders do not want a new council. In one community within the Kabul District of Surobi, the community's Malik and elders believed that they already had a council and that the NSP should work through them. Everywhere in the community, people would point to the Malik as their leader and decision-maker. The Malik and elders thus felt justified in their claim and refused to agree to elections and women's participation. SDF threatened to leave them and move to another community if they did not hold elections. SDF told them that even if their Malik was their leader SDF needed proof through elections to begin the NSP process. The community agreed that they wanted the NSP in their village, so eventually they agreed to elections out of fear that they might lose their chance in getting the NSP. (Incidentally, the Malik was not elected by the community in their CDC elections.)

In Faryab a community selected in the first year refused the NSP contract on grounds that the NSP was not serious and they would get provincial capital (Maimana) development funds and benefits. After a year they realised their mistake. They said they saw how successful NSP was in development work and they had seen how it was developing the other villages. They wanted the NSP back and they agreed to elections and women's participation, because the women were gaining benefits too. ACTED then included them in their next round of NSP communities with their full cooperation.

AfghanAid ${ }^{34}$ reported that in the first year they came into contact with communities who had been previously misinformed about the NSP:

The NSP was a new programme and many people, including government officials, did not understand its objectives. One district governor went around to communities in his district and told them that he was going to make sure they were included in the NSP because the NSP would give each family $\$ 250$ in cash. He then explained to them that this was their deserved right from the government. This caused a lot of problems for us, when our people (from AfghanAid) came to explain the NSP, the peop'e were expecting us to give them cash. When we explained the NSP objectives and that NSP was not about giving cash, they were very disappointed.

This sort of misinformation led the community to distrust AfghanAid and not want to agree to accept the NSP in their community. However, after many workshops and after getting many authorities involved, including the District Governor, they were able to clarify the misinformation. The communities of that district were eventually able to sign their contracts and fully participate in the NSP.

All FPs interviewed reported experiences of some form of resistance from communities in agreeing on women's participation, especially in the first year of the NSP. It was often noted that a given FP may currently reject any community that

${ }^{33}$ D. Omari, Currently AREU's Local Governance Research Assistant, was formerly a Peace-building Trainer for SDF in 2003.

${ }^{34} \mathrm{M}$. Simons and $W$. Ameri and M. Hallo, 2005, AREU interview with AfghanAid Community Development Director, NSP Coordinator and NSP Manager, AfghanAid Head Office, Kabul, Afghanistan, Feb. 23, 2005. 
does not agree to women's participation, but previously was lenient on this issue. The difference may be in the specific contexts of provinces, districts or just time. Multiple FPs reported cases of CDCs in the first round who did not agree to women's participation but now have and are forming women's councils. AREU's field visits confirmed this; however, there are fewer first year communities in Nangarhar creating women's CDC councils than there are in Herat.

Both $\mathrm{SCA}^{35}$ and DACAAR ${ }^{36}$ gave examples of women's participation causing the rejection of the NSP in their community on the grounds that it meant the NSP was a Communist programme. This was especially apparent in Pashtun areas that had previous Community Based Councils during the time of Daud's regime. IRC ${ }^{37}$ reported that some leaders ${ }^{38}$ who had lost power in CDC elections sent out reports denouncing the NSP as a Khalqi (Communist party or PDPA) programme or that it was an effort to convert people to Christianity. In such cases the FPs' only defence was to effectively communicate and convince people that the NSP was a government programme. This was done in a number of ways: either such allegations were resisted with the use of Islamic principles and verses from the Qur'an supporting the NSP process and inclusion of women, or the FP brought in government representatives to support the NSP, or it took time for the communities to realise such allegations were not true.

BRAC $^{39}$ reported (and AREU's field visits to Nangarhar confirmed) that communities such as those in Nangarhar did not take the NSP seriously and for that reason did not agree to the process. Communities did not believe in the NSP, thought that it would never come true, and that the funds would not be issued. They did not have confidence in the government administration to provide them with funds and they did not have confidence in the NGO, because so many NGOs had come before with empty promises. Instead of moving on to other communities, BRAC started the NSP process with members of communities who were willing to participate. They had to create community cluster level CDCs to get enough people to participate. Later, once the money came and the projects were started, community elders came to BRAC and asked for new CDCs to be formed so that each community would have their own. It was only then that they realised the NSP was a real programme and took it seriously. Unfortunately this delay in the process had serious consequences on elections, the CDPs and women's participation.

\subsubsection{Forming the CDCs}

Once the contract is signed, the FPs mobilise the community to elect their CDC. This is another level where conflict with traditional/existing powerholders/structures arises. At first, there is almost always some level of resistance to forming the CDC from traditional existing councils, elders and Malik/Arbabs. Their power of decisionmaking for the community is challenged by the CDC and they are afraid of power loss.

\footnotetext{
${ }^{35}$ Torngard, AREU interview of SCA's NSP Manager, March 19, 2005.

${ }^{36} \mathrm{~L}$. Wan, AREU interview with DACAAR's NSP manager, DACAAR Head Office, Kabul, Afghanistan, March 1, 2005.

${ }^{37}$ M. Payson and T. Usman, AREU interview with IRC NSP Managers, IRC Head Office, Kabul, Afghanistan, Feb. 20, 2005.

30 IRC reported that these leaders had been supported by the District Governor and gave them seats in the District Council despite not being elected by their community. They further reported that it was often the District Governor that felt threatened and even caused violence against the FP.

${ }^{39} \mathrm{M}$. Shahjahan and S.J. Hossain, AREU interview with BRAC director and NSP Manager, BRAC Head Office, Kabul, Afghanistan, Feb. 28, 2005.
} 
Three FPs implementing NSP in the north, including ACTED, ${ }^{40}$ AKDN $^{41}$ and UNHabitat, ${ }^{42}$ reported that there were cases where community powerholders actively worked against the formation of the CDC. It was usually key decision-makers of the community-elders, traditional shura members, Nawabs (large landowners), commanders-who would try to completely block the process. AKDN reported that they completely pulled out of such situations in two instances. However, UN-Habitat reported that they would work with the District Governors to convince the leaders to stop blocking the process.

Four FPs-AfghanAid, BRAC, MADERA ${ }^{43}$ and SDF ${ }^{4}$-reported communities who asked to form their councils by appointment instead of elections. The communities, especially the leaders, felt they knew who would be elected to the council already. AfghanAid reported that they even brought a list to them with the people they felt would be elected to the council. In most instances, elections were insisted upon. SDF told such communities that they may be right; however, they had the opportunity to officially prove their council through elections. They all reported that where there were elections the people who were elected were usually not on the list. However, in some communities where there were security concerns, such as in Nangarhar, elections were not held and those who were appointed were taken as the CDC members.

Powerholders of a community who are key decision-makers often expect to be elected. If they are not elected this also causes problems in the aftermath of the CDC elections. DACAAR, UN-Habitat and $\mathrm{CHA}^{4 s}$ gave similar examples of how powerholders did not accept the results of the elections. DACAAR reported one case in Laghman where the Malik was not elected and started firing a weapon. This caused a person to be injured. DACAAR's Social Organizer for that community went to the District Governor and informed him of the problem and was able to resolve this conflict through the District Governor. Similarly, DACAAR reported a Nawab who had ruled his community for $\mathbf{4 0}$ years. When he was not elected to the CDC he did not accept the elections and he went to the District Governor. The District Governor wrote a letter in favour of the Nawab, calling for DACAAR to include him in the CDC. DACAAR then had to go to the District Governor and explain the NSP process. After some back and forth, the Nawab agreed that though he did not recognise the CDC he would not bother its work in the community. UN-Habitat reported a similar instance in Herat where a local commander was not elected to a CDC, when he expected to be. He caused a lot of problems, so UN-Habitat held elections again. In the second round of elections he was not elected either, but he was satisfied with the results and stopped working against the CDC. CHA reported going through the same process with commanders who did not accept the $C D C$ election results. Commanders were not elected in the second round of their elections either and finally accepted the results.

\footnotetext{
${ }^{40} \mathrm{E}$. Kronoff and A. Krummacher, AREU interview with ACTED's NSP Manager and M \& E Officer, ACTED Office, Kabul, Afghanistan, Nov. 22, 2004.

${ }^{11}$ S. Mason, AREU interview with AKDN's NSP Programme Manger, AKDN Afghanistan Head Office, Kabul, Afghanistan, Feb. 21, 2005.

$42 \mathrm{~K}$. Zaifi, AREU interview with UN-Habitat's NSP District Manager, Enjil, Herat and Gender Coordinator, UN-Habitat Herat Office, Herat City, Afghanistan, July 4, 2005.

${ }^{43} \mathrm{M}$. Brillet and Safi, AREU interview with MADERA's NSP technical advisor and NSP manager, AREU's Head Office, Kabul, Afghanistan, March 8, 2005.

47. Shafiq, AREU interview with SDF's NSP Manager, 2005.

45 A.W. Hamidy and W. Farhodi, AREU interview with CHA's NSP Managers, CHA Kabul Office, Afghanistan, Feb. 23, 2005.
} 
In order to reduce the conflict between the existing traditional shuras and the newly formed CDCs, AKDN and ActionAid have felt the need to define the functions of the $C D C$ and traditional shuras as different: the CDC is only for development. As AKDN reports:

There are a few cases of traditional shura members on the CDC who are sometimes a delegate from the traditional shura; but generally we define the CDC as different than the traditional shura in that the CDC is about project delivery. Also, traditional shura members choose not to stand because of this differentiated function. It may be that they are not interested or because they don't think they will win the election and it is better for them to save face by not even trying. ${ }^{46}$ But in the future, what will happen if all the governance is within the CDC and the CDC is more and more active? At that stage I believe there will be more conflict. Right now though, there is a heavy appreciation of the democratic process and people understand why they are not elected. ${ }^{47}$

At a sub-district or mantega level, FPs have had to contend with commanders of village clusters, who have made demands on the NSP. One type of demand reported by ActionAid has been controlling the decision-making of multiple CDCs to do a multi-community project that often benefits the commander more than the communities. Due to this phenomenon, any project that is being requested by more than two communities raises red flags and comes under suspicion when being reviewed for acceptance by the Oversight Consultants of the NSP. Projects of such nature are rejected through careful negotiations.

Recent AREU field research in Faryab and Nangarhar indicated that there are cases of CDC members seeking to exploit CDCs, though it is not systematic. This is especially becoming the case where a CDC member is running in the 2005 parliamentary elections. In Nangarhar, field research found CDC leaders who were candidates claiming and promising projects through the CDC in order to gain popularity and votes.

\subsubsection{Handling interference}

All of these ways of dealing with interference in the NSP process are retro-active and have only been able to deal with the problems in a temporary manner, leaving the ability for such conflicts with power structures to re-occur with the next CDC election, the change of district and/or provincial governor, or the next CDC project. Furthermore, we are seeing CDCs gaining power in realms beyond development which include community conflict resolution-a role of the traditional councils-and political representation on district, regional and provincial councils. As the CDC's power shifts and changes beyond the realm of development, the CDC is posing new threats to existing power structures. This will inevitably cause some forms of conflict between the existing power structures and the new NSP power structures. Retro-active measures to ease this conflict may not prove effective in the long run and have not always been able to solve the problems.

\footnotetext{
${ }^{46}$ According to NPP Strategy Document for the National Solidarity Programme, prepared by the JPU for NSP, June 2004: To avoid selection of unwilling candidates, community members will have an opportunity to declare (prior to the election) that they are not prepared to accept the position if elected. All members of the community are eligible candidates until they take the positive step to declare themselves ineligible (p.5).

$\$ 7$ Mason, AREU interview with AKDN's NSP Programme Manger, 2005.
} 
Instead of retro-active measures that many FPs find themselves inadvertently using, the NSP needs pro-active preventive strategies. Pro-active strategies need to bring existing powerholders on board, give them ownership in the programme and integrate them into peace-time community leadership positions whether within the NSP or forming local governance structures.

IRC ${ }^{43}$ has come up with an effective strategy to do this. IRC has found that when you invite key stakeholders and ask for their advice on a project, in this case the NSP, they take on ownership of that project. For Oxfam, ${ }^{49}$ such interactions of advice came more organically:

In Dai Kundi we found that the CDCs make sure other powerholders (of the community) are not neglected. If they are not members of the CDC then their advice is sought before a decision is made. Furthermore, before and after a decision is made they have a large meeting like a town hall meeting where the whole community is invited to help decide and advise and the decision is made by the whole community. People like the Arbabs, the Mullahs and the landlords are big implementers of projects assigned by the community. Mullahs have influence by advising the CDCs.

IRC took deliberate steps to integrate such processes into the implementation of the NSP. Thus, with this idea of asking for advice guiding their approach to facilitating the NSP, IRC began their NSP work by setting up two advisory councils at the provincial level: the Masharano Shura and the Ulema Shura. To the Mashrano Shurah, IRC invited the Provincial Governor, District Governors, ministerial departments, Loya Jirga members, jihadi commanders, tribal leaders and three representatives from the Ulema Shura. The religious scholars and leaders of the province were also invited to a separate Ulema Shura.

The Masharano Shura started with a two-day workshop. After the participants were introduced to each other, they spent time understanding the NSP and the roles and responsibilities of the social contract of agreement. They got a chance to see the types of documents needed for the NSP and to go through the core values of the NSP and the FP (IRC), as well as comment on their own community's values to be included in the contract the community signed with the FP and MRRD. On the second day of the workshop they were given time to discuss and give their advice on how to implement the NSP, on village selection, and subsequently they created an NSP action plan for their province.

The Ulema Shura members were given the specific task to respond to the NSP documents from a religious standpoint. They were asked to give religious advice on women's participation in NSP, elections and community roles. They were subsequently also given the task to comment on the Universal Declaration of Human Rights, the Human Rights and Citizenship Declaration and the Islamic Human Rights Declaration. The Ulema Shura formed a sub-committee called the Special Action Committee for Religious Affairs (SACRA). This sub-committee was responsible for sending Imams/Mullahs to communities to explain the NSP and to help the facilitators mobilise participation in creating the CDCs. SACRA's responsibilities include:

\footnotetext{
48 Usman and Payson, AREU interview with IRC NSP Managers, 2005.

$49 \mathrm{~S}$. Wali, AREU interview with Oxfam's former NSP Programme Manager, AREU Kabul Office, Kabul, Afghanistan, Jan. 6, 2005.
} 
- Assisting Facilitators making CDCs to:

$>$ Explain to community members:

- The importance of making councils, considering religious values;

- The function of the council;

- The benefits of making the council; and

- How the council affects the empowerment of a community.

$>$ Encourage people of the community to take part in the reconstruction of their destroyed country through the NSP.

$>$ Describe the role of women taking part in the CDC and the importance in Islam of women's membership in humanity.

$>$ Explain the important role of women according to Islamic values and with examples.

$>$ Describe how Prophet Mohammad (PBUH) took advice from his wives and consulted with them in different circumstances.

- Solving problems and conflicts between community members if they arise during the formation of the CDC.

- Evaluating complaints received from community members about the NSP and CDC.

- Advising NSP managers and other officers on how to keep communities healthy in special circumstances.

Before hiring NSP staff and prior to the Social Organizers and Community Facilitators going into the communities to start the NSP work, IRC did an in-depth profiling of each community, identifying the powerholders and the disadvantaged-profiling the commanders, unemployed youth, widows, etc. They did this as a way of identifying the key stakeholders to involve in the process as well as to assess who might have positive or negative influences on the NSP in a given community.

Subsequently they turned to all the provincial level people they had previously consulted with on the Masharano and Ulema Shuras and asked each of them to give IRC a list of $\mathbf{2 4}$ people recommended to work with IRC on the NSP. IRC contacted each of these recommended people for CVs and used this as their employment pool for all the NSP staff of that province. Since these two shuras included members of diverse factions of powerholders, their employment pool was also inclusive of these different factions. IRC then short listed, interviewed and hired based on qualifications for the NSP jobs of that province. In this way they had key stakeholders guaranteeing the employees' work, they were able to find enough qualified people to employ and 99 percent of their staff were from the provinces they were working in.

As a result IRC had credible, reputable people represent the NSP to the community in an authoritative manner that the people could trust. They had religious leaders introduce the NSP to the communities as well as locally reputable and well connected NSP staff managing, entering the communities and mobilising "their own people". Traditional shura members were invited to join the NSP training and were trained to explain NSP to the community. This reduced and diffused a lot of opposition. Furthermore, because the employment pool was connected to different factions of powerholders, they acted in balancing each other so that no one powerholder could capture a project to their benefit.

Before community leaders were asked to sign the social contract, they were asked to add their own core values that the NSP should follow in their community to the contract. Often they added core values based on religious principles as well as customary codes such as Pashtunwali. 
The Mullahs of the community also helped in the election process. Due to their perceived neutrality, credibility and reputation for trustworthiness in communities, the Mullahs were employed to help non-literate people vote. Mullahs also announced the results, which were often coupled by an oath and swearing in of CDC members and a short prayer for the success of the community and its representatives. Cases have also been reported where Mullahs have resolved objections to the NSP election process, such as the taking of women's photos for voter registration cards. They also have been entrusted to take care of the ballot boxes if the elections run for more than a day.

IRC employed an innovative accountability mechanism. They appointed the commanders, Maliks and/or Mullahs (whoever were community powerholders but not elected) as part of the monitoring team to check the accounting and procurement processes and to make oral reports. This way those powerholders who were left out of the NSP election system were given an opportunity to take part and be integrated and encouraged into peace-time leadership roles. Large donations from commanders, Maliks and Nawabs towards NSP projects also signal this move towards community projects that benefit the collective leading them into popular peace-time leadership.

The communities' trust in the programme and its processes is also exemplified in community loans made by wealthy members to NSP sub-projects and by donating space for NSP-related trainings and courses. According to IRC there is $\mathbf{4 0}$ percent new leadership in CDCs and yet people still feel confident in the ability of the CDCs. IRC quotes a CDC member in the Herat CDC exchange programme as saying, "Under NSP we found that we have the rights to make decisions for ourselves and for our country."

\subsubsection{Drawing on international experiences: traditional power structures}

AREU's preliminary research findings seem to support the concept that the democratic process can integrate traditional power structures into the NSP-causing re-alignment to the central government, but also beginning a process of restructuring with the emergence of new power. One thing is for sure, local governance structures and even a stable, sustainable, "legitimate and functioning" Afghan state will not succeed if existing traditions of meaningful power structures are not incorporated.

The experiences of post-conflict Indonesia, East Timor and Malawi provide concrete examples of this. In these areas, local governance structures that did not incorporate traditional culturally appropriate local institutions had neither the legitimacy nor enough authority to function in the local community. Furthermore, local government institutions that were formally part of the central government were resisted in Indonesia and East Timor due to the history of government abuse.

Traditional institutions are networks that "sustain meaningful practices" which are "significant vehicles for political action"..$^{50}$ In Indonesia, citizens at the community level were left marginalised when traditions of meaningful local governance to nonJavanese citizens ceased to be recognised and were banned so that they could not openly practice them in a central government effort to impose one form-the culturally dominant Javanese form-of local governance. Furthermore, those who did

\footnotetext{
${ }^{50}$ A. Bebbington, L. Dharmwan, E. Fahmi and S. Guggenheim, 2004, "Village Politics, Culture and Community-Driven Development: Insights from Indonesia," Progress in Development Studies, 4(3):191.
} 
not adopt and accept government-backed Javanese local government structures were disempowered from public decision-making processes, public resources and development projects. ${ }^{51}$ This meant that effective links between traditional communities that did not adopt the imposed form of local governance and the government were weak. In turn, weak links of the government to local communities caused hindrance to government projects and impediments to the implementation of government reforms and development. In the final analysis, local governance was ineffective when it was not mediated through cultural practices and power relationships that were meaningful to the community.

In East Timor, due to the lack of meaningful institutions and the progressive marginalisation of traditional communities, parallel institutions of authority have functioned within local communities. . $^{52}$ New systems of governance that disregarded the traditional paradigms of trust and authority based in family lineage and descendents were rejected as being too foreign for assimilation. While the central government supported non-traditional democratisation strategies and posts, they did not enjoy legitimacy at the local level. With a history of East Timorese not having trust in government structures, international interventions aimed at institutionbuilding failed when they did not integrate local paradigms of meaningful practice into the governing structures. ${ }^{53}$

On the contrary, in Malawi, local governance was found effective when they incorporated traditional forms of meaningful authority into their local structures. In Malawi the government incorporated traditional chiefs/leaders into local government, legitimising programming and implementation. Not only did the traditional leader provide legitimacy to the local government, it also provided an essential link of meaningful practice between the community and the government. ${ }^{54}$

In Afghanistan, the NSP is based on a traditional form of governance i.e. councils such as jirgas or shuras. However, the people who sit on the new NSP CDCs are not all traditional leaders. New power is emerging due to marginalised parts of the community coming to the centre to participate in decision-making. However, this also means that some traditional and existing powerholders are left out. The situation of those left out needs to be carefully addressed. As international experiences point out, it may be that the sustainability and effectiveness of the NSP is closely linked to how well CDCs can be incorporated into communities' meaningful practices of political action and how well traditional legitimacy and authority can be incorporated into CDCs. Consequently, the key concept is to link customary with formal governance structures.

${ }^{51}$ Bebbington, Village Politics..., 201.

52 Hohe, Clash of Paradigms in East Timor, 585.

\$3 Ibid, 586.

54 M.K. Hussein, 2003, "The Role of the Malawian Local Government in Community Development,"

Development Southern Africa, 20(2):280. 


\section{Box 2. Payment of CDC members}

CDCs gain communal legitimacy as project implementers where concrete outputs of their work can be seen. However, if CDC members cannot devote enough time to the CDC project because they need to generate income to live, the projects are delayed and CDC legitimacy is weakened. Payment of CDC members has been proposed as a solution to this issue, though it remains controversial.

Currently in the NSP, CDC members are supposed to be volunteers only reimbursed for their travel. However, a few FPS have ononymously noted the need for CDC members to be paid some form of a stipend for their time spent doing CDC work. This is because the CDC work can be so time-consuming that it takes the CDC members away from their regular income generating activities and cuts their level of income. According to BRAC and further supported by AREU's fleld observations, 30 - 40 percent of elected CDC members are from marginalised groups, previously not part of the local power structure. To maintain that CDC participation is not just for the wealthy and powerful who have leisure time to volunteer, CDC members can be paid a small stipend so that they can meet their needs while they volunteer their time to CDC projects. CDC members in the Herat exehange and at the National Public Consultation Jirga unanimously requested to be paid a stipend.

The FPs interviewed for this study feel that if the CDCs are to be sustainable, then there should be some effort to at least make up for this gap instead of economically punishing those who are doing service to their community. CDC members may be more inctined to continue with CDC activitles ofter FPs leave and actively look for donors for future projects if they are paid. Since the Operational Manual is silent on this matter, IRC has taken up the issue and come up with a short-term solution until policies can be changed. IRC has integrated active, engaged CDC members as trainers and focilitators into the implementation of NSP in other villages, and have chosen to pay these CDC members. They also value and account for the CDC members' time consumed by their NSP work in the community. This leods to increased monitoring and supervision of the projects by the CDC members to ensure that the community workers are present and actively doing their job. Active supervision also increases outputs so that supporting CDC members frees some of their time up from income generation activities and allows them to more effectively do their appointed jab of project. implementation.

Similarly, in Pakistan, Union Council members are pald an honorarium in order to make up for this very same gap between Income generation activitles and community service. Similar to CDCs, Union Councils operate on a village cluster level and have male and female elected representatives, with the female quota at 33 percent representation. The Union Councils' responsibilities include supervising local schools, health clinics and local taxes. One of the problems with the honorarium discussed at the March 2005 Gender Mainstreaming and Millennium Development Goals Conference in Islamabad was that there was no consistency between genders and across provinces, Often times the honorarium, which ranged between Rs $500-1000$, wos neglected. Most other UC members reported that when they were poid, female UC members were only paid Rs 500 while male members were paid Rs 1000. However, Balochistan was the only province which was consistent in its payment and paid men and women equal honorariums of Rs 1000 . This inconsistency is caused by the societal view that men are the sole income generators of their family so they have a greater need. This fails to take into consideration the value of femole contributions to the family's needs and sustenance which may or may not have immediate economic value."

In the NSP context of Afghanistan, IRC pays the male CDC members since they can travel and act as supervisors over the male workers on their projects. This leaves the female CDC members out of the picture. Based on studies of female CDCs visited in Bamyan, female CDC members also spend considerable amounts of time away from their regular household activities to fulfil their CDC responsibilities. While they may not travel for procurement, they do invest time in planning meetlings and female projects within their village. If stipends are given according to time spent on projects such as IRC's form suggests, women's time should also be taken into account. However, if there is a flat honorarium, equity should be ensured. Such equity would encourage women to take equally active roles as the men, in their responsibility to represent and serve their community. Overall, stipends are a controversial issue among development practitioners because they can reduce elected leaders' responsibility to the community, thus mechanisms of stipend disbursement need to be sought to ensure communal accountability.

' S.S. All and F. Effendi, Gender Equality and Women's Empowerment, workshop discussion at the 2005 Gender Mainstreaming and Millennium Development Goals Conference, Islamabad, March 29th, 2005. Information cathered from discussion with Union Council Members oresent. 


\subsection{Summary}

Retro-active measures to ease tensions between existing power and new power of the CDCs may not prove effective in the long run. It is worth noting that the preexistence of NSP in a region and its demonstrated effectiveness reduces initial resistance to the NSP. However, neither retro-active measures nor pre-existence of NSP has been able to solve the problems faced by FPs and CDCs and conflicts with existing powers. It is through pro-active strategies that bring the existing powerholders on board, give them ownership in the NSP and integrate them into peace-time community leadership positions that meaningful legitimacy can be gained at the community level and the NSP objective of creating a "legitimate functioning state" can be met. Pro-active integration is both integrating and legitimising through giving powerholders advisory roles to the CDCs.

Paying small stipends has the possibility of increasing the responsibility of the CDC members to their elected roles and increasing their productivity on the CDC projects, ensuring that no family is burdened. CDC members' greater participation and productivity can further the communal legitimacy of CDCs as project implementers and sustain their role as a council in the community. Mechanisms of stipend disbursal may be a tool that can ensure leaders' accountability to their community. 


\section{Forms of Women's Participation}

One of the new types of leadership the NSP is gradually ushering into communities is a sort of women's leadership. The inclusion of women on CDCs has, in some instances, given a platform for women to discuss their ideas and potentially influence development. However, giving legitimacy to women's opinions, decisions and right to information has been riddled with problems. Contextually, while the state of women's rights in Afghanistan has been given a lot of international attention, Afghan institutions and programmes such as the NSP have not specifically addressed this problem. One reason for the lack of gender inclusive programming may be that "for the majority of government officials in Afghanistan, a gender approach is regarded as an elusive theoretical import with little contextual relevance". ${ }^{55}$ Where the gender approaches presented by the international community may be elusive and irrelevant to the context of the Afghan government, they lack even more understanding and applicability to the communities who outright reject them.

Where the NSP is rolling out, many communities have not agreed to comply with the requirement to include women in elections or in CDC membership (if elected). ${ }^{56}$ Still, FP reports and field research have found that there are many ways in which women are participating in

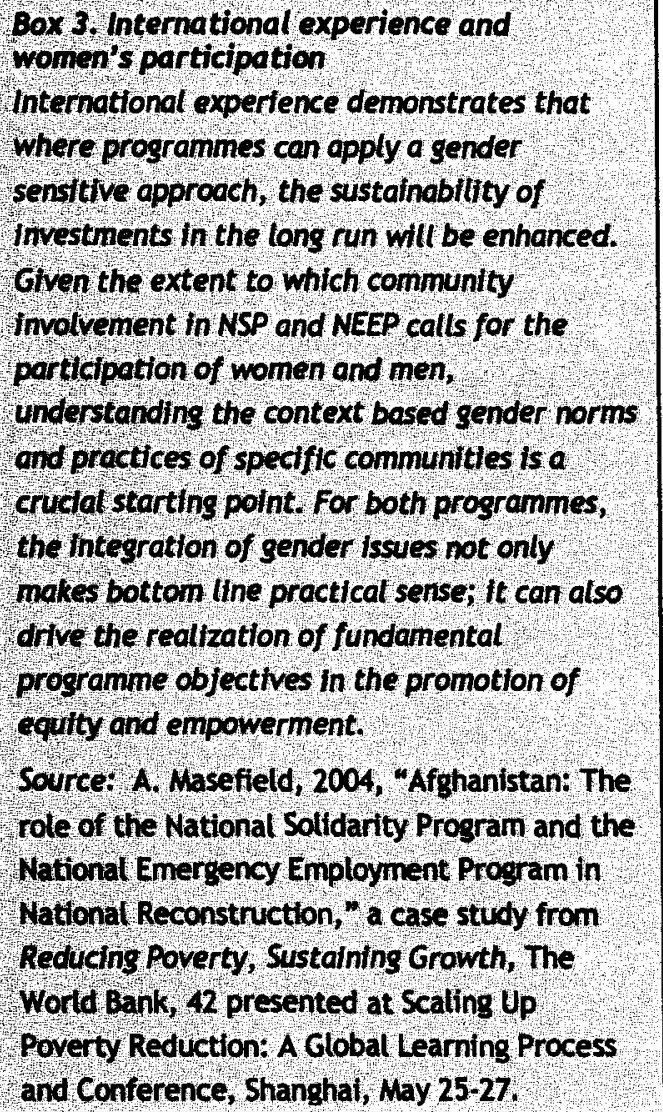

Box 3. International experience and 's participation where programmes can apply a gender sensitive approach, the sustainablity of Investments in the long run will be enhanced. Given the extent to which community involvement in NSP and NEEP calls for the participation of women and men. understanding the context based gender norms and proctices of specific communitles is a cruclat starting point. For both programmes the thitegration of gender issues not only makes botton line practical senise; it can also drive the realization of fundamental programme objectives in the promotion of equity and empowerment.

Source: A. Masefield, 2004, "Afghanistan: The National Emergency Employment Program in National Reconstruction, a case study from Reducing Poverty, Sustaining Growth, The World Bank, 42 presented at Scaling Up and Conference, Shanghai, May 25-27.

the NSP. Where women are already recognised within their community's cultural context as leaders or have recognised talents in management, community organising or accounting, they have been elected not only to their CDCs but also as leaders in their CDCs. Though this situation is rare, over half of the FPs have been able to name an example of one or two such cases. The next section further illustrates the way women are (and are not) engaged in CDCs.

\subsection{Types of CDCs and women's participation in them}

AREU research has found three main types of women's participation in CDCs:

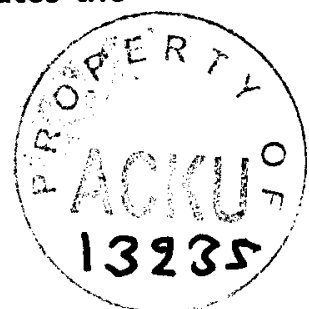

\footnotetext{
${ }^{55}$ A. Masefield, 2004, "Afghanistan: The role of the National Solidarity Programme and the National Emergency Employment Program in National Reconstruction," a case study from Reducing Poverty, Sustaining Growth, Washington, DC: The World Bank, 42; presented at Scaling Up Poverty Reduction: A Global Learning Process and Conference, Shanghal May 25-27.

${ }^{56}$ According to the NPP Strategy Document for the National Solidarity Programme, prepared by the JPU for NSP, June 2004: The CDC will be established through an election conducted according to the following rules: Everybody in the community who is entitled to vote in government elections is entitled to be registered as a voter... Both men and women are eligible to vote and to be members of the CDC (pp 4-5).
} 
1. Mixed CDCs

Type a. Women equal participants with men, elected by general election, sit together

Type b. Women only have token role, elected by general election, sit together

2- Segregated CDCs

a. General election, women and men elected but sit separately

3- Women's CDC branch

Type a. Elected separately by women, sit separately

Type b. Appointed by women, sit separately, role only to advise on women's concerns

\section{MIXED CDCs}

The ideal form of a CDC that exists, though rarely, in Afghanistan is the mixed CDC of men and women who are equal participants and decision-makers. This form seems to exist where women already have outspoken public roles in the community. Especially in communities where women leaders pre-date CDCs, which happens across ethnicities in Afghanistan, women are elected and participate in the CDC. Moreover, in all such cases mentioned by FPs, ${ }^{57}$ these women are further elected to leadership positions within their CDC.

The not-so-ideal side of mixed CDCs happen in communities where women do not have publicly vocal roles. Still there are cases where women are elected to the CDCs to comply with NSP policy. Unfortunately, the majority of mixed CDCs fall into this category. Often these women CDC members are token members who do not participate in discussions or decision-making. They may not even attend the meetings except when the FP is present. AREU field research in Bamyan found that women may send a male relative to sit in on the meeting in their place. However, in most cases they may want to participate, but in the mixed setting such women may have a hard time speaking up or having their words respected enough to be considered.

\section{SEGREGATED CDCs}

The NSP compromise to mixed CDCs are gender segregated CDCs. Women are allowed to participate in elections and be selected as CDC members. Then both men and women are popularly elected to the CDC by the whole community but the men and women sit separately. Both meetings are part of the same CDC. They share and discuss each other's written minutes. They may also have representatives that go to each other's council and report back and forth, such as the son or husband of a female CDC member or the wife, sister or mother of a male CDC member.

\section{WOMEN'S CDC BRANCH}

A common problem in women's participation in the NSP is that communities do not allow women to participate in elections for mixed gender representation due to their cultural norms. In other words, communities do not like men to vote for both men and women, nor women to vote for both men and women. In some communities such as those observed in Herat, ${ }^{58}$ FPs (DACAAR and UN-Habitat) have been able to convince communities to allow women to vote and elect only women to form a

${ }^{57}$ Of the $17 \mathrm{FPs}$ interviewed, 15 offered at least one example of CDC leaders who were women.

58 AREU Herat Field Research, June 22-July 6, 2005. 
women's branch of the CDC. In such cases, men vote for male representatives for the men's CDC and women vote for female representatives for the women's CDC.

In other cases, such as in the Rodat District of Nangarhar, ${ }^{59}$ communities do not allow women to participate in elections at all. Instead, a few select women who are interested, have some degree of mobility in the community, and may have some level of education are asked by the FPo or appointed by the women of the community to form the women's branch of the CDC. Therefore, there are two types of women's CDC branches and each case depends on whether women are allowed to elect each other or not.

Often FPs such as IRC use this second form of a women's CDC branch to give input to the male CDC decision-making and to represent some form of women's voices in the community where women are not allowed to participate in elections or have their own council. The women's branch may act more as an advisory or lobby group to lobby for specific projects the women want. The first type of women's CDC branch mentioned usually take on a more formalised role and may share their minutes with the men's CDC or have a male relative represent the women's CDC to the men's CDC and back. This representative would summarise the points of each meeting to the four key members of the CDCs-president, deputy, treasurer and secretary.

The problem with all of these forms of segregated CDCs is that it is still up to the men to make the final decision since they sign for the money and the bank account is registered to them. The men can choose to integrate the women's opinions or not. There is no formal mechanism that ensures women's decisions are taken into account and integrated with men's decisions.

For this, DACAAR has come up with an interim solution and is working with MRRD and the Oversight Consultant to further solve this problem. DACAAR ${ }^{61}$ has the men elect the male CDC and the women elect the female CDC. Each is registered with MRRD to be recognised as separate CDCs. However, the Oversight Consultant only issues them one bank account. At this point only the men can sign for the bank account. DACAAR has worked out a system to try to balance the decision-making. Not only do the two CDCs have to share and review each other's minutes, they have to share financial records to ensure they have access to the same information as well as each taking turns to implement a project to balance the decisions. Therefore, if the first project was implemented by the male CDC to build a road, for example, the second project cannot be implemented by the men. It is then the women's turn to implement a project. The Community Development Plan is pre-negotiated between the two CDCs so that the projects and order are agreed upon before implementation begins. ${ }^{62}$

Another problem is that women request projects that are not gender-specific (e.g. gender-specific projects include female income generation projects such as tailoring). These projects include infrastructure projects such as bringing accessible drinking water to the community. Since it is commonly understood that only 10 percent of the budget is allocated to women's projects, ${ }^{63}$ this is often not enough for

\footnotetext{
s9 AREU Nangarhar Field Research, Aug. 23-Sept. 1, 2005.

${ }^{60}$ Observed FP in Nangarhar was BRAC.

${ }^{61} \mathrm{~L}$. Wan, AREU interview with DACAAR's NSP Manager, March 1, 2005.

62 DACAAR has not yet instated this practice in all the provinces for which it is facilitating the NSP and this practice was not observed in Herat.

${ }^{63}$ According to NSP guidelines, at least 10 percent of the block grant in a given community should be set aside for projects that serve vulnerable people and women, however, this is merely a guideline and does not mean only 10 percent of projects can be oriented toward these populations.
} 
women to implement such infrastructure projects. However, this 10 percent is also supposed to benefit all vulnerable groups, including widows and the disabled, and thus it is not exclusively for women. Furthermore, it is commonly misunderstood as a maximum of 10 percent whereas it is a minimum of 10 percent and according to the Oversight Consultant, ${ }^{\text {t4 }}$ more funds can be requested for such projects.

DACAAR's solution to these problems is for the women's CDC to have their own account to which their allocation of funds could be transferred. They are further recommending to MRRD and the Oversight Consultant that women be given a higher allocation of the funds to be able to cover the costs of such infrastructure projects. A higher allocation would also give women more control over spending and decisions of projects, since the men and women would have to work together on their CDP, especially if they decide on fewer projects with higher costs. Women's CDCs would have more decision-making power because they would have to approve the use of their allocated percentage of the budget if it is a significant enough percentage to make a difference i.e. at least 30 percent or more. Even if women were to have higher allocations and more control over the spending for their projects, due to their cultural norms and/or security situations that limit their mobility, they would also have to work with men to go to the cities and do procurement for their projects. The DACAAR form fails when women are not allowed to vote and elect women to the CDC. In such cases they can form a women's council, however, it is not official and does not get the registration status that an elected women's CDC can get. DACAAR has found these councils to be less effective.

IRC's effort to increase women's participation focuses on this problem of women's involvement in elections and councils. IRC works through the SACRA, which their Ulema Council sets up (see previous section). This committee sends trained Mullahs and works to train the community religious leaders along with FP staff and CDC members. They work through Islamic principles of women's rights, including the right to take part in consultations through elections and councils. This may include Friday sermons on women's rights to convince the whole community along with the leaders. This has proven effective in getting women to vote in some of the most conservative communities according to IRC, however, they are still having problems with setting up women's CDCs.

SCA also felt the need to couch NSP in traditional and Islamic concepts, however, was wary of forcing women's participation:

We need to present the NSP in traditional frameworks and define it in traditional words. We can use Islamic concepts from the Qur'an of financial and social responsibility and equality. Otherwise the NSP might seem like a programme where we give dollars to access their women. How much are we abusing their culture just by offering the help of \$200? Human rights need to be addressed in the rural areas but if it is seen as a bribe system they might spit it out and not take in everything. Then women's participation in CDCs will not be sustainable. ${ }^{65}$

SCA has come up with a strategy where female CDC members have to sign and approve all projects along with the male CDC members whenever there are gender segregated meetings of any form. While women have to sign, there is so much

\footnotetext{
64 This issue was raised in correspondence with Lorene Flaming, Acting Head of MGE Unit, NSP.OC, July, 19, 2005. See also NSP Operations Manual, Dec. 2004.

${ }^{65}$ Torngard, AREU interview of SCA's NSP Manager, March 19, 2005.
} 
illiteracy, it is not hard to assume that women often may not know what they are signing if they cannot read it. Furthermore, the pressures of tight deadlines for getting projects approved may also cause oversight in making sure women have access to the same information the male $C D C$ members have access to. While in theory SCA's measures seem sound, the lack of literacy and capacity of women hampers their effective participation.

\subsection{Other challenges to women's participation in the NSP}

In addition to impediments facing CDCs, there are a number of other major problems surrounding women's participation in the NSP. FPs' experiences have highlighted the following as being major impediments to women's participation:

- Staff gender biases;

- Cultural norms that prevent women from voting, being elected and attending meetings;

- Lack of time to educate and overcome biases and detrimental norms;

- Women's decisions not having legitimacy or credence and women not having access to information and funds;

- Lack of women's leadership experiences and literacy (lack of capacity); and

- Lack of structured means of ensuring segregated female CDCs influence decision-making.

\subsubsection{Staff Gender Bias}

Gender biases exist at all levels of the NSP and FPs have acknowledged that due to the gender biases present in Afghan society, some of their staff also carry such biases. Often identifying these biases and their effects is hard, especially by national-level managers of the NSP. However, they do recognise it is there. There are areas where no women have CDC representation, yet the women of such communities have set up their own councils to lobby to the CDC without the help and much to the anguish of the FP. FPs such as IRC have set up special gender programmes with regional positions to address these biases and work to overcome them.

According to the World Bank study regarding the NSP's ability to reduce poverty, "Facilitating partners are expected to recruit and deploy female field staff to enable the inclusion of women in prioritisation, decision-making and implementation processes." ${ }^{66}$ Along these lines IRC ${ }^{67}$ has further set a policy within their gender programme to try to overcome this bias effect by aiming to have 50 percent of their employees as women. Right now they are at 33 percent. Furthermore, 99 percent of their staff are locally hired. Similarly, SCA tries to follow the policy of having $\mathbf{5 0}$ percent of its staff locally hired, the reason being:

Women in (rural areas) have the right to be mobilised by people who respect them. You know sometimes staff from Kabul do not respect rural women that is why we try to hire at least half our staff locally. ${ }^{68}$

Overall, gender biases at all levels of the NSP, national and international, need to be targeted in systematic ways to ensure women's participation is a priority. Whether

\footnotetext{
${ }^{66}$ Masefield, Afghanistan: The role of the National Solidarity Program, 18.

${ }^{67}$ Payson and Usman, AREU interview with IRC NSP Managers, 2005.

68 Torngard, AREU interview of SCA's NSP Manager, March 19, 2005.
} 
there is gender bias at the field staff level, centrally hired or not, FP programming has tried to work with communities on women's participation in CDCs, as evidenced in the previous section.

\subsubsection{Lack of Time}

A major impediment to informing and training communities so that they understand the NSP process and requirements despite their gender biases and cultural norms is a lack of time. All the FPs claimed that the time frame to mobilise communities and set up CDCs was too short. Time is needed to lay the foundations for strong local governance structures as is part of the goal of the NSP. The obvious building blocks of this foundation are sound information and inclusive participation. If time is not spent on educating communities on the importance of inclusive participation, over half of the population-women-are left out of the decisions made by the community about its future.

\subsubsection{Lack of Women's Capacity}

Once women are elected to CDCs, there is a low participation rate. Many FPs attribute this to women's lack of confidence in their own skills due to lack of relevant management and leadership experience. AfghanAid has worked to solve this problem by focusing on capacity building and management training to try to develop a next generation of confident, effective female leaders. Where women are allowed to participate in elections, AfghanAid has mixed CDCs. However, they have realised that women are not attending CDCs regularly and when they do, they do not participate. Therefore, they have set up women's groups who lobby and implement small projects; it is through these groups that they try to build their capacity for leadership. Women are given the same training courses as the CDC members are-in management, proposal writing, accounting and procurement. However, they are given further courses in health education and NSP training-where they discuss what is happening with the NSP in their community, and community resource management training. It is a five year project so that these women are prepared for the next CDC elections $^{69}$ with the experience and skills needed to be active CDC members.

\subsection{Summary}

While there are major problems surrounding women's legitimacy and participation in the NSP, FPs have come up with innovative solutions to begin to deal with them. IRC is trying to overcome gender biases by developing specific regional gender programmes and increasing female staff to 50 percent. IRC is also using the Ulema Council's Special Action Committee on Religious Affairs to support the authority and give religious backing to women's participation in overcoming cultural norms. Lack of time remains to be a problem until the Oversight Consultant/MRRD chooses to change the time frame in which the basis of gender inclusive participation and elections is to take place. DACAAR has set up two separate CDCs in communities that take turns implementing projects to ensure women's decisions are taken into account and that they have access to the same information and funds. Finally, a five year capacity building plan is being implemented by AfghanAid to address the lack of women's leadership experiences, confidence and literacy to prepare a new generation of female CDC members.

\footnotetext{
${ }^{69}$ There is still some debate as to whether the elections will be held in two or three years. At the National Public Consultation Jirga (National level CDC Conference) Aug. 22-25, 2005, Kabul, one of the topics of discussion was whether the CDCs would be ready for elections every three years.
} 


\section{Potential NSP Linkages to Other Institutions}

The National Solidarity Programme was first conceived as a five to six year programme targeting all communities in Afghanistan. Initially, the idea was to make the NSP block grants part of the recurring budget of the Afghan government so that there would be funding going to the villages every year. Official NSP documents state that "the goal of the government is to establish a system of recurrent transfer of block grants for all village communities of the country...annual follow-up block grants will be allocated at a lower per capita rate (than $\$ 200$ per household) to be determined". ${ }^{70}$ However, at this stage communities finishing two years of the NSP are being told they will not receive

Box 4 . Scope of the NSP

The transitional government intends to have the NSP cover the country's estimated 20,000

villoges over a four year period, In the first year, three target districts have been selected by MRRO in each of the 32 provinces on the basis of vilnerability related to drought impocts and return of Internally Displaced Persons (IDPs) and refugees. The target for the first year of implementation is to reach more than 4, 100 village communities across the country.

Source: NPP Strategy for NSP, $2004,2$. any more NSP funding and they should look for funding elsewhere to implement other projects in their Community Development Plan.

According to the FPs interviewed for this study, clear communication about FPs' deadlines, coverage and output expectations with MRRD and the Oversight Consultant has been lacking. MRRD made statements to the effect that funding for the FPs was ending and that the programme would end after its third year. However, as of August 2005, correspondence with MRRD found that funding for FPs has been further extended.

The NSP reached 6,000 communities in the first year. In the second year the target was expanded to reach 4,500 more communities so that roughly half of Afghanistan was covered. This year, NSP's third year, there is still discussion as to the exact number of communities targeted, however, the number is around 6,000 more communities to be reached. As of July 2005, NSP had been initiated in 10,500 communities-roughly half of the communities in Afghanistan. Furthermore, the time spent with first year communities of the NSP (started in 2003-2004) has been extended to three years due to slower implementation than planned in the first round. ${ }^{\prime \prime}$

The June 2004 NSP Strategy Document, under the heading of "Key next steps to advance the programme", states: "The programme is currently exploring potential linkages with other national priority programmes and the education and health sector."72 This section of the paper looks at cases of such explorations of "potential linkages".

In lieu of the deadline for the NSP to pull out of their first year communities following the extended three years of funding, FPs are trying to pilot various exit strategies in order to be able to leave the CDCs functioning and standing on their own feet. The loudest complaint is that the CDCs are still in such a fragile state that

\footnotetext{
${ }^{70}$ NPP Strategy Document for the National Solidarity Programme, prepared by the JPU for NSP, June $2004,2$.

71 A. Johnson, Manager for Facilitating Partners Window Dept., Oversight Consultant Team, National Solidarity Programme, e-mail correspondence on August 21, 2005.

72 NPP Strategy Document for NSP, 2004, 8.
} 
they need lots of support over time (most estimate at least 5 years) if they are going to survive. Another repeated opinion expressed both by FPs and CDCs in the field is that if CDCs are left without support, those elements that are against them will figure out strategies to undermine them, so that when the next round of such community development programmes come around they will very effectively be able to stop them. The argument follows that if the government is discontinuing the use of FPs to support the NSP, it needs to come up with a way of supporting the NSP possibly by way of the central government or non-governmental centralised institutions. Furthermore, CDC sustainability depends on how well CDCs can be integrated and mainstreamed across ministries.

Some form of inter-ministerial cooperation at the local level is needed for the efficient use of resources. For example, there have been anecdotal reports of how little cooperation there is between the Ministry of Agriculture and Animal Husbandry (MAAH) and MRRD. Both ministries have large budget programmes but are implementing them separately without cooperation and information sharing where their programmes overlap. MRRD could benefit from using MAAH's extension agents ${ }^{73}$ to strengthen the capacity of CDCs and rural farmers' groups. MAAH could work more closely with the CDCs on their agricultural and animal husbandry projects. MAAH's interest groups around production, fertiliser, marketing, etc. could be coordinated with CDC interest groups to prevent overlapping. Without such coordination the interests of both MRRD and MAAH could be monopolised through conflicts caused by the confusion and turmoil between programmes at the local level.

\subsection{The World Bank's Integrated Approach}

In June 2004 World Bank published a study ${ }^{74}$ on local development that was a synthesis of theoretical work on the subject of local governance. The NSP was not part of the study nor has the WB been found to apply this study to the NSP; however, the theories are useful structures to explore links between local CDCs, government ministries, NGOs and private business sectors.

This study states that "local development is primarily the responsibility of local actors" and depends on "agency and action at the local level rooted in commitment by local actors to assume responsibility for improving their own well-being." means that:

- Local actors are empowered to make their own decisions about development;

- There is a local governance system through which people can act collectively; and

- There are provisions to support local actors through the government, private sector and NGOs through funds, training and technical assistance.

\footnotetext{
73 "A new activity to observe in this arena is the emergency seed and fertilizer distribution program which has been initiated by USAID. The idea is that MAAH extension workers and/or cooperatives or NSP CDCs (through RRD provincial reps.) will be used to identify beneficiaries and distribute seed and fertilizer vouchers depending on who (MAAH or MRRD) has greater capacity at the district level. This program is being implemented in all provinces, so NSP CDCs' will be taking a role in identifying beneficiaries." R. Wrobel, Peer review comments from NSP's OC Regional Support Manager, November 2005.

74 Local Development Discussion Paper, 2004, prepared for The International Conference on Local Development, June 16-18, 2004. Washington, DC: Human Development, Social Development and Public Sector Management Networks, World Bank, 10.

75 Ibid, ii.
} 
So far the NSP has focused on empowerment and local governance with development outputs but the creation of institutional provisions for support is severely lacking. What has been somewhat institutionalised ${ }^{76}$ in the NSP is a relationship with the District Governors, and the FPs have been working at different ranges and with differing levels of success at building this relationship. Successful relationships include:

- CDC members on the District Governor's Shura with reporting mechanisms;

- The District Governor and CDC in a referral loop so that they refer problems to each other;

- The District Governor protecting the CDC against elite capture by powerful leaders who were not elected to the CDC, such as commanders and large landowners; and

- The District Governor lobbying for CDC proposals for schools and clinics to the Provincial Governor and line ministries.

However, faltering relationships do occur where District Governors feel threatened by the power of the CDCs. In some cases, District Governors have actively resisted acknowledging the legitimacy of the CDCs and worked against them. DACAAR gave the example of a District Governor who supported the Nawab's claim of community leadership against the newly elected $C D C$. Furthermore, relations are strained where there are strong commanders in the region that the District Governor has to keep happy in order to keep his position. In Herat, a District Governor selected the communities to receive the NSP and had to include those communities where powerful commanders came from. When a community with such a powerful commander rejected the terms of the NSP and DACAAR pulled out, the District Governor accused DACAAR of not cooperating, and creating problems in the implementation process of the NSP.

According to the FPs' understanding, the new (December 2004) NSP Operational Manual calls for CDCs to be grouped into village clusters. This means representatives of CDCs would meet at a cluster level to discuss coordinated development efforts as well as meet around common interests. According to the World Bank the local level, which is equivalent to this cluster level in the NSP, is an effective level where sustainable local development can take place. This is because geographically the cluster level is where there are "primary nodes in market, transport, communication, and serice delivery netwarts that link small towns and their service catchments." Furthermore-from a social perspective-at the cluster level there are wider networks of interactions frequently facilitated by "associational or identitybased institutions." In the Afghan context mantegas ${ }^{73}$ might adequately describe this level where there are community clusters that are socially and economically interdependent.

Whereas at the community level there are face-to-face interactions at a single village or settlement, the local/cluster level can be more useful in development for the following reasons:

\footnotetext{
${ }^{76}$ All FPs reported building relationships with the District Governors through inviting them to initial informational sessions and following up with reports on current work. However, AREU field work in Faryab found that in the district of Almar the district administration had little idea of what was going on other than what the villages told them and rumour.

7 Local Development Discussion Paper, 2004, 10.

78 Muhalla may also be used interchangeably with the word mantega.
} 
1. It is small enough for effective communication from communities and to the local government, along with the ability to make timely use of it.

2. It is large enough to pool social and economic capital to support specialised interest groups.

3. It is large enough to have an economic or population basis for demanding allocation of resources from higher levels of government and other donors (private sector/NGO).

The main question that arises with a combination of a development decision making body at the local level such as in the NSP, in the context of a centralized government system, is where the final decision for a development project lies. The ministries of the centralised government of Afghanistan have their own plans and budgets whereas the CDC clusters are responding to the demands of their communities which may overlap multiple ministerial jurisdictions. ${ }^{79}$ This can be further exacerbated by the differing lines of accountability for development projects to different ministries and of the CDC to the community/FP/OC-MRRD. However, if the WB's proposed "Integrated Approach to Local Development" is applied both the centralised government plans and the CDC cluster demands can be taken into account. $^{80}$

One possible tool to prevent inter-ministerial conflict and promote cooperation is the World Bank's “Integrated Approach." The World Bank's "Integrated Approach" is a helpful tool for exploring interface mechanisms that ministries could use in mainstreaming CDCs into their ministerial programmes.

Figure 1. WB's Integrated Approaches to Local Development

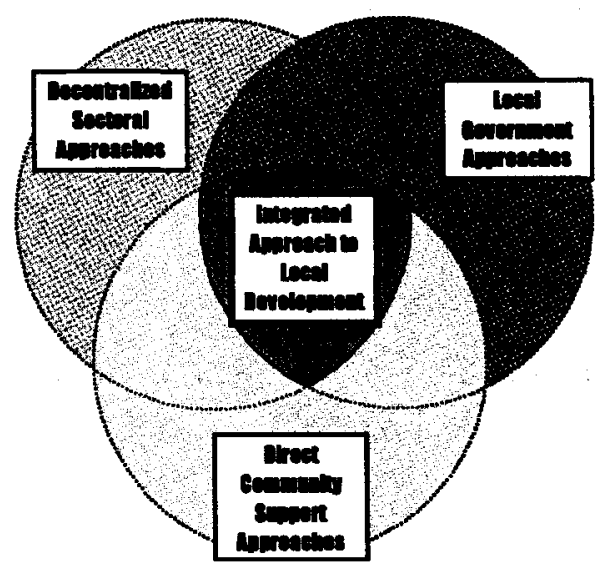

\footnotetext{
${ }^{79}$ For more information see: A. Evans, N. Manning, Y. Osmani, A. Tully and A. Wilder, 2004, A Guide to Governance in Afghanistan, Kabul: AREU; A. Evans, N. Manning, Y. Osmani, A. Tully and A. Wilder, 2004, Subnational Administration in Afghanistan: Assessment and Recommendations for Action, Kabul: AREU; and A. Evans and Y. Osmani, 2005, Assessing Progress: Update Report on Subnational Administration in Afghanistan, Kabul: AREU.

${ }_{80}$ "Decentralized sectoral approaches rely on functionally specialized organizations at the local level, with operational autonomy allocated through deconcentration or delegation policies. Local government approaches promote territorially organized political and administrative institutions, with policy and operational autonomy allocated through devolution policies. Direct community support approaches, such as those frequently associated with community-driven development, promote resource transfer and civil society empowerment strategies that emphasize community organizations as institutions of collective action and interlocutors between people and public service providers." See Local Development Discussion Paper, 2004, i-v.
} 
The WB's Integrated Approach combines the decentralised and direct community approach of the CDCs with the centralised approach of the government. Key to the foundation of the Integrated Approach is the re-aligning of power so that the focus is on local actors and the local community rather than national-level actors. The Integrated Approach recognises the need for the central government to provide strategic planning, technical assistance, and cross-sectoral resource allocation in the role of project facilitator, supervisor, and monitor. In this approach the CDCs would continue to work with their communities to come up with a development plan, then lobby their demands of service coverage to the central government, and finally act as implementers or intermediaries to the central government on their project. The Integrated Approach requires policy frameworks through which the CDCs' plans can be integrated into the central government's strategic plans, ministries can channel funds and technical assistance to CDCs and monitor projects.

In summary, the Integrated Approach's foundation lies in its focus on local actors and community where the central government's role is five-fold:

1. Facilitating the Integrated Approach through new policies

2. Strategic planning

3. Resource allocation

4. Technical assistance

5. Supervising and monitoring

The CDC cluster's role in the Integrated Approach would be three-fold:

1. Developing their Community Development Plan and negotiating plans at the cluster level;

2. Lobbying for projects; and

3. Implementing projects with technical assistance and under the supervision and monitoring of the central government.

Applying an Integrated Approach would imply CDCs would be in an institutionalised and ongoing relationship with the central government through multiple ministries. While MRRD is the only ministry that has policies which facilitate the Integrated Approach, the Ministry of Public Health has similar policies due to its monitoring role of NGOs who are providing Basic Health Packages in the districts. With limited central government policies to support such an Integrated Approach, FPs have had limited success in piloting links between the CDC and the line ministries. A major tension with the Integrated Approach to the Afghan government is the centralised nature of the government as opposed to a certain amount of decentralisation that the Integrated Approach includes. However, there are ways to work this tension out in the Afghan context and the following three cases are promising examples of such integration in the areas of disaster management, health, and education. 


\subsection{Three promising examples of CDC integration}

\subsubsection{The Case of the Kahmard Flood of July 2004: CDC Roles and Relations to Government and Aid"1}

On July $13^{\text {th }}, 2004$ starting at around 4pm, torrential rains poured over the Kahmard District of Bamyan Province. In less than an hour houses were flooded, roads were closed and by nightfall a mudslide had dammed a pool of water that blocked the main road into the valley.

Many villages lost their stored food, livestock and some harvest, but in seven villages, houses were seriously flooded if not destroyed and family possessions all lost. This left families without shelter, food and drinkable water. ${ }^{82}$

Within two days CDCs from the three villages of Madr, Laghki and Banaq, who were less severely hit by the floods, responded with help to those seven villages they were nearest. CDC members of the three villages asked their village members to donate what they could. From their personal supplies, families gathered oil, rice, flour and bread, the CDC rented vehicles and drove their donations as close as they possibly could by road. Then they sent the items through a representative of the village to the CDC president, along with a letter to the CDC. Once the items were received by the CDC of the affected villages, they distributed them to the worst hit victims in their villages. The CDC also wrote a letter of thanks and receipt of items and sent it back to the CDCs that had helped them.

Meanwhile UNAMA held a provincial level meeting to decide how to respond. At that meeting it was suggested that the CDCs be asked to make an assessment of the flood damage and a beneficiaries list. In the event, the CDCs gave much more moderate assessments than the government. MRRD, UN-Habitat, AKDN, UNHCR and Solidarites all decided to go along with this experiment and use the CDC beneficiaries list. Within 15 days they were able to gather 230 tents, 1443 blankets, 542 plastic sheets, 1000 plastic jars and 80 family kits.

An entourage of government officials and UN-Habitat personnel accompanied the relief donations. Though there was some redistribution by the Provincial Deputy Governor, at least two villages distributed the items according to their CDC list. Villages who were able to distribute items according to their CDC list felt it was a just distribution, though there were complaints that the amount of relief was not enough, i.e. there were not enough blankets to give to all those who were on the list.

Conclusively, CDCs were able to make assessments without having to inflate them due to power plays, foreign aid expectations (i.e. they expect more from foreigners

\footnotetext{
${ }^{81}$ Report summarised from findings through AREU's field research in Bamyan, Nov. 2004. Other examples of disaster management include, "when the Band-i-Sultan collapsed in Ghazni province in April 2005, communities in Khoja Omari and Ghazni Center were affected. NSP CDCs had been formed in both districts, and they were used as a focal point to produce beneficiary lists and distribute aid from UNAMA, Ministry of Ag., WFP, etc. The Ghazni RRD Directorate and the OC provincial of fice, as well as CARE and DACAAR, played a key role in facilitating contacts with the CDC representatives. The same thing happened more or less in Panjshir province in June of this year when floods cut off access to Keraman, Khenj and Paryan districts. NSP CDCs produced beneficiary lists, and aid materials were airlifted to the affected areas by UNAMA and the PRT." R. Wrobel, Peer review comments from NSP's OC Regional Support Manager, November 2005.

82 The seven villages were: Dehqan Qala, Deh Elgah Hajer, Deh Tajik Hajer, Deh Miana Hajer, Lorange, Chokri Dara, and Bajgah.
} 
than from Afghans) and better knowledge of their community. Secondly, the communities agreed with the CDC assessments and reinforced the CDCs' decisions by giving the relief items to the CDCs for (re)distribution. Thirdly, CDCs in Bamyan have district and provincial councils that have the potential to link into district and provincial planning and decision-making. Finally, the boundaries of the CDC authority are unclear in terms of whether they are accountable solely to their community or whether they are accountable to the hierarchies of government.

Evidence from this case study indicates that the success of CDCs in the area of disaster management lies in their ability to:

- Make quick damage assessments and beneficiary lists that the communities support;

- Mobilise relief from their own excess stocks to other communities; and

- Expedite distribution of relief from their vantage point.

Disaster management links could be further developed with:

- Regular CDC cluster level communication;

- Relief item stores readily accessible to vulnerable CDC areas; and

- Government policies that automatically work with and through CDCs in disaster management, relief distribution and disaster mitigation/prevention.

\subsubsection{The case of Wardak's health programme and CDCs}

In the province of Wardak, the Swedish Committee for Afghanistan (SCA) is both the Facilitating Partner for the NSP and the responsible NGO for the delivery of MOPH's Basic Package of Health Services (BPHS) under a Performance-based Partnership Agreement. SCA has made efforts to encourage the CDCs and the Health Councils to work together. These efforts have produced several links between the NSP and the BPHS.

According to SCA, female CDCs have taken on supervision of community health workers to ensure quality and equity of coverage. The reasoning behind such a project for the female CDCs was to give them a task that was achievable to build their capacity and confidence. Furthermore, through this project, female CDC members are encouraged to build a sense of communal responsibility and cohesiveness. Overall, such supervision provides opportunities for female CDC members to network with, work with and be aware of the health programme and health workers.

The SCA health clinics cover 20,000 individuals at a scale similar to CDC cluster sizes. Each clinic has a health committee. Due to the SCA's efforts to improve synergy between the NSP and health programme, most of the health committee members are also CDC members. Usually CDCs have appointed members interested in health who are then responsible to sit on the health committee at the cluster level. This acts as a cluster-level interest group in health and informs the decisions and needs of the health clinic in that regional cluster level.

Finally, SCA has linked the two programmes by making use of the CDCs' community profiles. While there is some mistrust of the CDC community profile made by the community instead of outside surveyors, the SCA has encouraged its use in various forms. Where the CDC community profile is trusted it is used as the survey of the community for the health programme, otherwise it is used as a follow up with other agency community profiles and surveys. SCA is working with CDCs to improve the 
accuracy of their profiles because they believe that the CDC should have the role and authority in the production of documentation of their community.

The factors that contribute to the success of the CDCs in the area of health, as reported by the FP, include:

- The health programme's accountability to the CDC in terms of CDC supervision;

- The health council being a platform where CDCs are empowered to lobby their demands; and

- Working with the CDC to build their authority of knowledge about their community.

Health programmes could be further developed by:

- Using the CDC members as health educators, to bring pressure into the community to change;

- Using the CDC to monitor and track disease and mortality;

- Giving the CDC responsibility in identifying candidates for health training; and

- Cross-facilitating development projects with the Basic Development Needs Programme (BDN) ${ }^{83}$ and the CDCs.

The role of the Ministry of Public Health could specifically involve relationships with CDCs through:"

- Policy and health laws formulation

- Strategic planning

- Resources allocation

- Training and technical assistance

- Supervising and monitoring

- Health information, education and communication.

\subsubsection{The case of district schools' rehabilitation window and CDCs}

Last year (2004), the World Bank funded an MRRD pilot of the District School Rehabilitation Window with the objective of promoting joint representation and planning around education at the local level. The Window provided half a million dollars to districts for school rehabilitation on the condition that they ensure joint representation process for joint planning on the entire district level. They wanted the lowest levels of representation to be included in the decision-making with the local government and for this they chose the district level since the provincial level was too big for such an endeavour.

\footnotetext{
${ }^{83}$ The main goals of the BDN programme are improving health and quality of life through involvement of all sectors and by reducing inequalities and inequities, incurring health expenditure according to the actual needs of the people and bridging the gaps with regard to the health, social and economic determination of inequity. WHO Country Representative to Pakistan, Dr. Khalif Bile quoted by The News in S. J. Amin, 2001, "Inclusion of BDN in Health Policy Sought," Oct. 30, 2001. BDN considers health as part and parcel of overall development. Health is a contributor to and product of development. All sectors are involved in the BDN programme so that intersectoral action can be maintained. The BDN approach is a process of organizing and mobilising community members to realise their health and development needs and work collectively to achieve them. A.A. Abdullatif, 1999, "Basic development needs approach in the Eastern Mediterranean Region" Eastern Mediterranean Health Journal, 5(1):168176.

${ }^{84}$ Developed in consultation with Dr. F. Kakar, Deputy Minister of Health, Kabul, Afghanistan, Aug. 2005.
} 
The project specifically targeted the pilots of eight districts to be in regions where NSP FPs were successful. They started in Badakhshan's district of Ishkashim. A council was formed to decide which schools should be rehabilitated. The council was made up of CDC, MRRD and Ministry of Education (MoEd) representatives. The WB reports that it was difficult learning process. This was because in the current central government system the chain of command is from the centre to the periphery (and vertically organised by ministries with little cross-sectoral planning), whereas this joint planning and representation form assumed that responsibility for decisionmaking and allocation of resources rested with the CDC representatives. This direct clash of systems caused confusion, as the MoEd representatives were not accustomed to listening and considering the ideas coming out of the communities who were receiving the school services. The MoEd has been structured so that the curriculum, planning and budget are done in Kabul, with the provinces making specific decisions about where to place the schools and teachers they have budgets for and the districts carrying out the plans. In other words, for demands to be coming from the school's community instead of from the centre was confusing to MoEd even though the WB budget went directly to the district.

The CDC representatives also had some difficulties understanding that the budget was only for rehabilitation of schools that already existed. In order for the schools to qualify to receive this funding they needed to be registered with MoEd and have staff and teachers. Yet CDC members wanted to expand the number of schools in their district, which often didn't meet the qualifications of being registered or having existing staff, which ultimately could not be taken into the MoEd's plan.

The second pilot in Baghlan's district of Anderab was more successful. They were able to be clear about their requirements and qualifications from the start. This ensured clear goals so that the council was able to cut the chase and get right to the task at hand of choosing the schools in the district to rehabilitate. According to the WB, the Anderab council was able to come up with their own criteria for choosing the schools. Then by democratic process they ranked each of the schools in the district. Finally they ended up with a list of the most needy schools to rehabilitate, which everyone agreed on and were satisfied with.

CDC members were able to bring their concerns to be included in creating criteria and voting on schools. They were empowered to decide, had a forum to act through to meet their demands, and the WB and MRRD were able to follow through with funding and technical assistance. The CDCs were able to help propose and monitor the project at the cluster-level education council.

\subsection{Risk factors: local agents' overload and burn out}

While CDC clusters are an ideal scale to link to service provision schemes, one problem that seems too early to measure with the NSP, is over burden or burn out of CDC members, especially where few members are involved in many projects and councils. According to international experience, there is a great possibility for burn out to happen if preventative measures are not taken into account.

In Tanzania, PAMOJA, the Kilimanjaro Joint Action Project, was working to cultivate and bolster human resources through creating cooperative and collaborative social institutions for the sustainability of local agents-both government and civil. PAMOJA is based on the premise that the government will be stronger if "it can 
count on more willing co-operation and self-enforcement among the citizenry". ${ }^{85}$ in other words, not only do local communities need the human resources to be able to run local governments themselves, they need the resources of educated and fully motivated citizens.

PAMOJA's approach to local governance was through bolstering human resources by creating local networks of agents with similar functions. The aim of these networks was to create an institution of active trust at the community level through demonstrating the benefits of cooperation and collaboration in participatory structures. The idea was that this in turn would allow for human resources to be cultivated in a sustainable way through integration, dialogue and exchange of information. However, PAMOJA's approach has met with challenges in sustaining commitment of people to its networks. While they were able to start networks, some community members ended up being parts of many networks and became overcommitted and eventually burnt out. Other community members started regular networking and eventually found the commitment too burdensome to their work. ${ }^{86}$

Similarly, SCA, CARE and UN-Habitat voiced concern over burn out of CDC members being tasked to multiple councils. UN-Habitat gave the example of there being too many councils in one village, which made leaders exhausted and confused over jurisdiction of each council. This can be streamlined by having CDC members or interested community members who report to the CDC liaison and participate on cluster-level councils.

\subsection{Role of CDC Clusters ${ }^{37}$}

According to FP reports, AKDN and UN-Habitat had started forming and had existing CDC clusters and interest clusters, while other FPs were still in the planning stages. What seems to work in all these examples of CDC links are the cluster-level interest groups which maintain a wider pool of interested and qualified participants and may prevent burn out. These cluster groups decide their criteria and rank their demands. Then they lobby their demands to higher level officials who have control of the budget, whether they be government or NGOs contracted by the government. The central government should then have a way of integrating these demands into their planning and budget according to their own strategies based in their technical knowledge. Then if the government issues a budget to the cluster-level CDC, they should also have a built-in monitoring mechanism to supervise and monitor how the CDC is implementing the project. If there are Provincial Development Committees that are the decision-makers about which community development projects get funding (as recently approved by the Cabinet), then the mechanisms for lobbying might have to change. ${ }^{88}$

\subsection{Summary}

While there is no comparison to FPs continuing to work with CDCs as facilitators and guides, the funding for NSP demands that the FPs eventually withdraw and allow the

\footnotetext{
${ }^{85}$ R. Van Klinken, 2003, "Operationalizing Local Governance in Kilimanjaro," Development in Practice, 13(1): 72 .

${ }^{86}$ R. Van Klinken, "Operationalizing Local Governance in Kilimanjaro," 80.

${ }^{87}$ FPs use different terms for the cluster level that range from sub-district, geo-regional to howza and manteqa.

88 Setting Up the Provincial Development Committee with in Provincial Administration, Revised Draft of Policy Paper, Aug. 3, 2005.
} 
CDCs to function independently. The CDCs need ways to maintain legitimacy and continue with their CDPs despite the exit of the FP from the scene. Building links with other institutions, structures and networks would help the CDCs maintain legitimacy and sustain their role. According to the June 2004 WB study on local development, the CDC cluster level is the best level to work with to form links to centralised institutions and the government. An integrated approach should be taken to ensure that all levels of government and institutions connect to the local level of the CDC cluster. The central government's ministerial level can integrate through drafting new policies, strategic planning, allocating resources, providing technical assistance, supervising and monitoring the CDC cluster projects. The CDC cluster's role would be to develop a cluster-level CDP, lobby the government for projects and implement the projects with the help and supervision of the government's appropriate ministry.

CDC clusters could develop more specialised and detail-specific roles based on the ministry and area where they are needed. CDC interest clusters could be formed to deal with specific areas. Examples of roles CDCs have employed in disaster management include making damage assessments and beneficiary lists, mobilising local relief from surplus stocks, and expediting distribution of all forms of relief. In the area of health, CDCs have participated on health councils, supervised health programmes, lobbied for improvements, and done community surveys; however, their roles and activities lend themselves to be health educators, and monitor and track disease and mortality. CDCs also have demonstrated the ability to build criteria, propose, lobby and monitor the school projects in the area of education.

The findings from the three cases on CDC relations with central institutions ${ }^{89}$ can be summarised as:

1. There is most potential where the local scale of activity between CDCs and central institutions is complementary.

2. There is tension between local input through CDCs and centralised, vertical state structure.

3. While some CDCs are more able to take on an institutionalised role, not all CDCs have the same capacity yet.

Overall, CDC clusters have much un-reaped potential to be the point of contact with communities on all levels of service provisions. CDC legitimacy and sustainability can be bolstered through building these networks and links with the central government and non-government institutions.

\footnotetext{
${ }^{89}$ Central institutions are meant to include both central government ministries and NGOs.
} 


\section{Conclusions and Recommendations}

While the findings from this study are preliminary, there are a number of lessons that can be taken from discussions with FPs implementing the NSP across communities.

\section{Integration of traditional powerholders into the NSP process}

While traditional powerholders can be an impediment to successful implementation of the NSP, many communities have found CDCs to be meaningful forums for political action when pro-active integration with existing power structures takes place. In some communities, stakeholders were invited to participate on a council of advisors at the provincial level to discuss the NSP roles and responsibilities and to create a plan of action for the NSP. When they were invited to become a part of the NSP process they took ownership and supported NSP CDCs. This was especially helpful when religious leaders actively visited communities and supported the NSP, as well as encouraged women's participation in the programme. Therefore, one way CDC legitimacy can be gained is through pro-active integration of existing and traditional power structures through:

- Inviting stake/power holders to advise the NSP's process in their community.

- Creating formal councils for stake/power holders with a supporting role to CDCs. This includes recognising stake/power holders who genuinely are working to integrate into peacetime leadership roles as opposed to those who are seeking to abuse the system for their own benefit (though making this sort of judgement may prove problematic).

- Considering the option of paying CDC members a small stipend to meet the income gap and to increase time able to be devoted to CDC work.

- Fostering general inter-ministerial cooperation on strategies to integrate the CDCs into the official government system, especially with the Ministries of Interior, Health, Education and Agriculture and Animal Husbandry.

\section{Increasing women's participation and decision-making roles}

Women's participation and decision-making power is a difficult challenge to tackle because of the community and even national-level cultural institutions that choke it. When gender specific programming was introduced into communities (such as by IRC), ${ }^{90}$ the focus immediately raised the awareness of staff and communities alike to the issue at hand. The majority of FPs have found that religious justification could be effectively used to convince communities of the value and appropriateness of women's participation and the importance of their decisions. When stakeholder councils took action to educate communities (with religious justification) about the importance of women's participation and decisions, it was most effective. However, where there were not formalised responsibilities of communication between the men and women, women's decisions were not integrated well into the CDC programming. Women were able to integrate their opinions and decisions when they had to authorise the men's CDCs projects and spending or when projects were done in turns between the men and women's CDCs. Literacy was a major barrier to women effectively following structured routes of authorisation and communication. Lack of literacy and leadership experiences caused women to feel less confident, as a result hampering women's participation. Conclusively, women's participation and legitimacy can be facilitated through:

\footnotetext{
${ }^{90}$ See section on Forms of Women's Participation.
} 
- Increasing female staff to 50 percent and gender awareness programmes for staff.

- Legitimising women's participation and decisions through powerholders' councils including religious justification.

- Creating structured routes of communication and authorisation between male and female CDCs.

- Building women's capacity through literacy and leadership courses.

\section{Integration of CDCs with centralised institutions}

The CDC cluster level is the best level to work with forming links to centralised institutions and the government. An integrated approach ensures that all levels of government and institutions connect to the local level of the CDC cluster. CDCs have proven their efficacy in disaster management where they are able to mobilise their own disaster response to help victims, build beneficiary lists that are shorter and more credible than others, and help distribute relief. CDC clusters have been useful to the MOPH's BPHS programme through CDC representatives appointed to health councils participating, lobbying, and building community health history through surveys. CDC clusters have been able to work with provincial governments to build criteria for schools' rehabilitation, including proposing, lobbying and monitoring. Overall, CDC legitimacy and sustainability can be reinforced through such links where the central institution: ${ }^{91}$

- Facilitates an integrated approach through new policies

- Plan strategies (strategic planning) of how to integrate CDC cluster

- Allocate resources to implement plan

- Provide technical assistance to CDC projects

- Supervise and Monitor Implementation of CDC projects

CDC clusters can be formed as a point of interaction with central institutions, who:

- Develop a cluster level development plan

- Lobby for projects to government and non-government institutions

- Implement projects at cluster and village levels

However, caution is advised since the capacity of CDC varies and considerable work may be needed to improve CDC functioning and representativeness.

\footnotetext{
${ }^{91}$ Central institutions are meant to include both central governmental ministries and NGOs.
} 


\section{References}

Abdullatif, A.A. 1999. Basic development needs approach in the Eastern Mediterranean Region. Eastern Mediterranean Health Journal. 5(1):168-176.

Bebbington, A., L. Dharmwan, E. Fahmi and S. Guggenheim. 2004. Village Politics, Culture and Community-Driven Development: Insights from Indonesia. Progress in Development Studies. 4(3):191.

Evans, A. and Y. Osmani. 2005. Assessing Progress: Update Report on Subnational Administration in Afghanistan. Kabul: Afghanistan Research and Evaluation Unit.

Evans, A., N. Manning, Y. Osmani, A. Tully and A. Wilder. 2004. A Guide to Governance in Afghanistan. Kabul: Afghanistan Research and Evaluation Unit.

Evans, A., N. Manning, Y. Osmani, A. Tully and A. Wilder. 2004. Subnational Administration in Afghanistan: Assessment and Recommendations for Action. Kabul: Afghanistan Research and Evaluation Unit.

Dupree, L. 1966. Aq Kupurk: A Town in Northern Afghanistan. South Asian Series. $X(10)$ (Afghanistan):13.

Ghani, A. 1978. Islam and State Building in Afghanistan. Modern Asian Studies. 12(2):271.

Hohe, T. 2002. Clash of Paradigms in East Timor. Contemporary South Asia. 24(3):570.

Human Development, Social Development and Public Sector Management Networks, World Bank. Local Development Discussion Paper 2004. Prepared for The International Conference on Local Development. Washington, DC. June 16-18, 2004.

Hussein, M.K. 2003. The Role of the Malawian Local Government in Community Development. Development Southern Africa. 20(2):280.

Masefield, A. 2004. Afghanistan: The role of the National Solidarity Programme and the National Emergency Employment Program in National Reconstruction. In Reducing Poverty, Sustaining Growth. Washington, DC: The World Bank. Presented at Scaling Up Poverty Reduction: A Global Learning Process and Conference, Shanghai May 25-27.

Mendoza, K. 2004. Islam and Islamism in Afghanistan. Afghan Legal History Project, Harvard Law School. Available online at: http://www.law.harvard.edu/programs/ilsp/alhp.html

Pain, A. 2004. Understanding Village Institutions: Case Studies on Water Management in Faryab and Saripul. Kabul: Afghanistan Research and Evaluation Unit.

Rasanayagam, A. 2003. Afghanistan: A Modern History. London: I.B. Tauris.

Roy, O. 2003. Afghanistan: Internal Politics and Socio-Economic Dynamics and Groupings. UNHCR-WriteNet Paper.

Tarzi, A. 2003. The Judicial State: Evolution and Centralization of the Courts in Afghanistan, 1883-1896. Ph.D. dissertation. New York University. 
Van Klinken, R. 2003. Operationalizing Local Governance in Kilimanjaro. Development in Practice. 13(1):72.

Vogel, F. 2003. "Understanding Muslim State Paradigms and Afghanistan." Afghan Legal History Project Lecture, Islamic Legal Studies Department, Harvard Law School. Cambridge, MA. 


\section{Recent Publications from AREU}

Aug 2004 Rural Land Relations in Conflict: A Way Forward, Liz Alden Wily

Aug 2004 From Subjects to Citizens: Local Participation in the National Solidarity Programme (NSP), Inger W. Boesen

Dec 2004 Looking for Peace on the Pastures: Rural Land Relations in Afghanistan, Liz Alden Wily

Jan 2005 Transnational Networks and Migration from Herat to Iran, Elca Stigter

Feb 2005 Transnational Networks and Migration from Faryab to Iran, Elca Stigter

Feb 2005 Who Owns the Farm? Rural Women's Access to Land and Livestock, Jo Grace

March 2005 Caught in Confusion: Local Governance Structures in Afghanistan, Sarah Lister

March 2005 Afghans in Karachi: Migration, Settlement and Social Networks, the Collective for Social Science Research

April 2005 Transnational Networks: Recognising a Regional Reality, Elca Stigter and Alessandro Monsutti

May 2005 Bound for the City: A Study of Rural to Urban Labour Migration in Afghanistan, Aftab Opel

June 2005 Assessing Progress: Update Report on Subnational Administration in Afghanistan, Anne Evans and Yasin Osmani

June 2005 Return to Afghanistan? A Study of Afghans Living in Tehran, University of Tehran

Aug 2005 A Guide to Parliamentary Elections, Andrew Reynolds, Lucy Jones and Andrew Wilder

Aug 2005 Emerging Trends in Urban Livelihoods, Stefan Schütte

Aug 2005 A Place at the Table: Afghan Women, Men and Decision-making Authority, Shawna Wakefield and Brandy Bauer

Oct 2005 Return to Afghanistan? A Study of Afghans Living in Mashhad, University of Mashhad

Oct 2005 Return to Afghanistan? A Study of Afghans Living in Zahedan, University of Tehran

Oct 2005 Alternative Livelihoods: Substance or Slogan? Adam Pain and David Mansfield

Oct 2005 Understanding Markets in Afghanistan: A Study of the Market for Petroleum Fuel, Anna Paterson

Oct 2005 Understanding Markets in Afghanistan: A Study of the Markets in Second-hand Cars, Anna Paterson

All AREU publications can be downloaded from www.areu.org.af. Hard copies are available by contacting the AREU office in Kabul.

\section{Afghanistan Research and Evaluation Unit}

Charahi Ansart (epposite the Insaf Hotel and Popolano's Restaurant),

Mobile: $+93(0) 70276637$. Email: areu@areu.org.af 


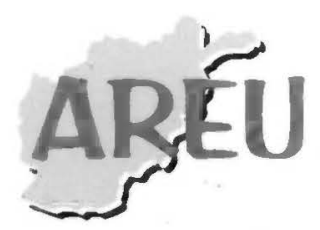

Afghanistan Research and Evaluation Unit

Charahi Ansari

(opposite the Insaf Hotel and Popolano's Restaurant)

Shahr-e-Naw, Kabul, Afghanistan

Phone: +93 (0) $70276-637$

E-mail: areu@areu.org.pk Web: www.areu.org.pk 